\title{
BOYUTSAL AÇIDAN MÜZIKK
}

\section{DYNAMIC OVERHEAD MUSIC}

\author{
Mustafa KABATAȘ
}

$\ddot{O} z$

Müzik eğitiminin sorunları giderek karmaşıklaşmış olan insanın hümanist kimliğine kapsamlı ve yeni olanaklar kazandırmaya yönelik kurgulanması gerekliliğinin görülmesini sağlayacak bilimsel çalışmalara gereksinim olduğu düşünülebilir. Araştırmanın problemini; Günümüz müziğini incelendiğinde, Müziğin Psikolojik boyutu, Müziğin Felsefi boyutu, Müzik Sosyolojik boyutu, Müziğin kültürel Boyutu açısından Müzik Sanatı nasıldır sorusunun yanıtı aranmaktadır. Bu araştırma; müzik eğitiminde, müziği araştırma alanlarında değerlendiren bilim dallarının verileriyle oluşturulmuş kuramsal bilgi birikiminin alan ĕgitimine yapacă̆ katkl, bu çerçevede, müzik bilimlerinin çok boyutlu olarak incelenmesi amaçlanmıştır. Bu araştırma; Günümüz müziğini incelendiğinde, Müziğin Psikolojik boyutu, Müziğin Felsefi boyutu, Müzik Sosyolojik boyutu, Müziğin kültürel Boyutu açısından Müzik Sanatının değerlendirmesi, genel bir bakış açısıyla incelenmesi ve araştırmacılara, alan uzmanlarına kaynak teşkil etmesi açısından önemlidir. Araştırmada, Günümüz müziğini incelendiğinde, Müziğin Psikolojik boyutu, Müziğin Felsefi boyutu, Müzik Sosyolojik boyutu, Müziğin kültürel Boyutu açısından Müzik Sanatının değerlendirmesi, genel bir bakış açısılla incelenmesi betimlemeye çalışılmıştır. Araştırma nitel araştırma yaklaşımına uygun, betimsel tarama modelindedir.

Anahtar Kelimeler: Müzik, Müzik Felsefe, Müzik Sosyoloji, Müzik Kültür, Müzik Psikoloji

\begin{abstract}
It can be considered that the need for scientific studies to ensure that the problem of music education is seen as a necessity for the increasingly complicated human being to construct humanist identity in order to gain comprehensive and new possibilities. The problem of your research; When we examine today's music, we are looking for the answer to the question: What is the art of music in terms of the psychological dimension of music, the philosophical dimension of music, the sociological dimension of music, and the cultural dimension of music. This research; Contribution to the field education of the
\end{abstract}


theoretical knowledge which is formed by the data of the sciences which evaluates in the field of music education in the field of music education is aimed to examine the music sciences in a multidimensional way in this frame.

Keywords: Music, Music Philosophy, Music Sociology, Music Culture, Music Psychology

\section{GİRIŞ̧}

Müziğin çeşitli bilim dallarının araştırma alanının kapsamında yer alması, belki doğrudan doğruya kulağımıza ulaşan sesin kalitesiyle ilintili değildir. Ancak çoğunlukla kulağımıza ulaşan sesin bizi nasıl yönlendirdiğiyle ilintilidir. Bunlardan birisi müzikolojiyi müziği mantıksal yöntemlerle araştıran bir disiplin olarak ele alırken, diğeri müzikolojiyi müziğin bir dalı, bir bilgi alanı olarak görmektedir. Müzikolojinin bir başka tanımı ise "Müzik sanatını fiziksel, psikolojik, estetik ve kültürel görüngü olarak araştırmayı hedefleyen bilim alanı” olduğu şeklindedir. Müzikolojinin bir tanımı da şöyle yapılabilir: "Müzik alanında var olan kuramların (yapılan bilimsel araştırmalar ve deneysel çalışmalar sonucunda doğruya en yakın olduğu kabul edilen varsayımlar) geliştirilmesi, ya da tamamen yok edilerek yerlerine yenilerinin konulmasına yönelik yapılan bilimsel araştırmalar, deneysel çalışmalar ve bunların belgelenmesi’. Bu çerçevede müzik bilimi ile ilgili farklı birçok tanımın yapıldığı görülmektedir. Bilimi, doğa yasalarının çözümlenip belli bir sentez ile yeniden bir ürün haline getirilmesi gibi düşünecek olursak, müzik bilimi tanımını; müzik sanatını, fiziksel, psikolojik, felsefi, estetik ve sosyolojik açıdan ele alan bilim alanıdır" olarak ifade etmek doğru olacaktır. Müziği incelemek toplumu incelemek, kültürü müzik içinde kod çözümüne uğratmak, müzik üzerinden topluma ilişkin söylem üretmek, aynı zamanda tarihin sesini dinleyici ve besteciye ulaştırmaktır (Vural Yıldırım, “Türkiye 'de Müzikolojinin Müzik Alanına Katkıları", Orkestra Dergisi, İstanbul, 2003: 343).

Vural Yıldırım'ın söyleminden yola çıkarsak, müzikoloji alanının bir görevinin de toplumun sosyo-kültürel varlığının, müzik sanatı içindeki varlığını sürdürmesinde gerekli çalışmayı yürütmek, toplumda gerek dinleyici, gerek sanatçıya bu konuda kaynak olmak olduğunu düşünebiliriz. Müziği incelemek, müzik faaliyetinin birincisi olan müziği yapmaktan farklı bir uğraştır. Müziği incelemek: müzik adına kuramsal, yönteme dayalı, tarihi ve güncel verilerle çalışmaktır. Yapılan çalışmaların ortaya çıkardığı kültüre yönelik analojik saptamalar önemli bir yönlendiricilik üstlenir. Müzik üreticisi kompozitörden dinleyiciye kadar, birçok değişik konumdaki insan bu saptamalar doğrultusunda hareket edebilir (Vural Yıldırım, “Türkiye 'de Müzikolojinin Müzik Alanına Katkıları”, Orkestra Dergisi, İstanbul, 2003: 43-49).

Müzik bilimleri, müzik alanında düşünmeye katkı sağlar. Müziğin ontolojik boyutunda, yaratma sürecine yönelik düşünme eğilimidir. Böylece düşünce ve beğeni, ortaya çıkacak müziğin estetik değerlerini yapılandırır. Müzikte estetik, ezginin sadece müzikal değerlerini değil; bu değerlerin insana ulaşmasındaki süreçleri ve insana ulaştığında onda oluşan duyguları ve yargıları da değerlendirir. Müzik ile bilimsel süreçler arasındaki ilişkiyi inceleyen araştırmaların büyük bir bölümü müziği dinleyen ve 
algılayanlar üzerindeki göstergelerin incelenmesi biçimindedir. Çünkü bir biçimiyle yaşama geçen müzik, dinleyicinin kulağında olan müziktir. Müziği üretenin deneyimi ve performansı dinleyicinin algısındaki müziğin kalitesini garanti etmiş sayılır. Oysa günümüzün bilimsel araştırmaları bunu eksik bir bilgi olarak kabul eder. Müziğin üretim deneyimleri de araştırılmak zorundadır. Çünkü müzik üreten ve dinleyen grup eşdeğer eğitimden geçmemektedir. Dolayısıyla kulağa ulaşan müziğin kalitesini ne ölçüde dinleyen, ne ölçüde üreten belirlemektedir soruları kolayca yanıtlanamaz. Bir yandan dinleyenin müziği fark etme, algılama, saklama, dönüştürme, hatırlama, çağrışımlama, yeniden üretme boyutları incelenirken, diğer yandan müziği üretenin, ürettiği müziği hangi çalgı birikimi, ezgi estetiği ve estetik teoriyle ürettiği de bilinmelidir. Çağımızın müzik bilimleri her iki olguyu ayrı ayrı inceleyerek ilişkilendirmeyi daha verimli bir bilimsel yöntem olarak kabul eder. Müzikal algı oldukça karmaşık ve birbirinden farklı yetileri içermektedir. Müzik bilimlerinin; müziği üretildiği ortamın kültürel, toplumsal, politik, felsefi, edebi vb. birçok kıstas içinde değerlendirdiği, yorumladığı ve toplumun genel kültürel-sanatsal edim, üretim, bilgilenme, eğitim ve etkinliğinde yönlendirici rol üstlendiği söylenebilir.

\subsection{Araştırmanın Amacı}

$\mathrm{Bu}$ araştırmada; özellikle müzik eğitiminde, müziği araştırma alanlarındaki tüm bilim dallarına yapacağ1 katkı düşünülerek, bu çerçevede müzik bilimlerinin çok boyutlu olarak incelenmesi amaçlanmıştır.

\subsection{Araştırmanın problemi}

Araştırmanın problemini; Günümüz müziğini incelendiğinde, Müziğin Psikolojik boyutu, Müziğin Felsefi boyutu, Müzik Sosyolojik boyutu, Müziğin kültürel Boyutu açısından Müzik Sanatı nasıldır sorusunun yanıtı oluşturmaktadır.

\section{3. Önem}

Bu araştırma; Günümüz müziğini incelendiğinde, Müziğin Psikolojik boyutu, Müziğin Felsefi boyutu, Müzik Sosyolojik boyutu, Müziğin kültürel Boyutu açısından Müzik Sanatının değerlendirmesi, genel bir bakış açısıyla incelenmesi ve araştırmacılara, alan uzmanlarına kaynak teşkil etmesi açısından önemlidir.

\subsection{Yöntem}

Araştırmada, Günümüz müziğini incelendiğinde, Müziğin Psikolojik boyutu, Müziğin Felsefi boyutu, Müzik Sosyolojik boyutu, Müziğin kültürel Boyutu açısından Müzik Sanatının değerlendirmesi, genel bir bakış açısıyla incelenmesi betimlemeye çalışılmıştır. Araştırma nitel araştırma yaklaşımına uygun, betimsel tarama modelindedir. Nitel çalışmalar, doküman inceleme, araştırılması hedeflenen olgu ve olaylar hakkında bilgi içeren yazılı materyallerin çözümlenmesini kapsar (Yıldırım 2006; 187-189). Tarama modeli ise, "geçmişte ya da halen var olan bir durumu olduğu şekilde betimlemeyi amaçlayan yaklaşımdır" (Karasar, 2006: 77). 


\section{BULGULAR VE YORUMLAR}

\subsection{Müzik Bilminin Boyutları}

\subsubsection{Müziğin Felsefe Boyutu}

Sanat bilimleri boyutunda müziği ele almayı amaçladığımız bu bölümde özgün görüşler yerine sanat bilimleri alanında uluslararası düzeyde kabul görmüş görüşleri ele alan yazarların yapıtlarından alıntı yapılması tercih edilmiştir. Geniş anlamıyla müzik felsefesinin araştırma alanlarından söz etmek tezin amacını aşacağı için daha çok sanat felsefesinin müziği nasıl bir boyutta ele aldığına ilişkin görüşlere yer verilmiştir. Otto Karolyi müziğin özelliklerini şöyle algılar: Müzik hem sanattır, hem bilim. Dolayısıyla hem duygusal olarak algılanabilmeli, hem de akıl ile kavranabilmelidir. Herhangi bir sanat ya da bilim dalındaki gibi müzikte de, bilgiye ya da ustalığa giden yolda kestirmeler yoktur. Müzik dinlemekten hoşlanan ama müziğin dilinden anlamayan bir müziksever, tatilinde görmek için gittiği bir ülkenin doğal güzelliklerini gören, o ülke halkının davranış biçimlerine tanık olan, konuşmalarını dinleyen ama söylenenlerin tek bir sözcüğünü anlamayan bir turiste benzer. Duyar ama anlamaz (Otto Karolyi, Müziğe Giriş, çev. Mehmet Nemutlu, Pan Yayınları, İstanbul, 1995: 7).

Müziğin ussal ve yaşamsal algılanışı açısından insan yaşamındaki önemi tartışılmazdır. Felsefe, müziğin algılanışının ve değerlerinin nedenselliğini çeşitli ekoller 1şı̆̆ında incelemiştir. Felsefi algılayışa göre müzik bir sistemdir. Bu sistem şöyle açıklanabilir; Sanat bir düzendir. Sesle ilgili olan müzik de bir ses düzeneğidir. Ses, müziğin malzemesidir ancak sessizlik de müziğin malzemesidir. Müzik, düzenlenmiş ses yoluyla (alfabesiyle) oluşturulan bir dildir. Bu dil dönemlere, kültürlere, inanışlara ve yaşam biçimlerine göre farklı şeyler anlatır. Ancak bu farka rağmen yeryüzündeki bütün insanlar doğal olarak ses diline aşinadır (Otto Karolyi, Müziğe Giriş, çev. Mehmet Nemutlu, Pan Yayınları, İstanbul, 1995: 9).

Müziğin yaşamsal nedenselliğine şöyle bakılabilir: İnsanlar doğanın sağladıklarını her zaman hangi amaç için kullanırlar? Müziğin ortaya çıkması için temel bir zorunluluk olmalıydı. Bu zorunluluk nedir? Bir şey söylemek, bir şey anlatmak, seslerden başka bir yolla anlatılamayacak durumlarda oluşur. Sözcüklerle anlatılabilen bir durum için insan müziğe ihtiyaç duymaz. Renklerle anlatılacak bir durum resimde, güçlü bir anlatımla iletilirken, müzik ancak seslerle anlatılabilecek duyguları ve temaları içerir. Müziksel düşüncelerin öne sürülmesinin ardından kaçınılmaz olarak düzenlilik kuralları doğmuştur. $\mathrm{Bu}$ düzenlilik kuralları müzik düşüncesinin ortaya çıkışından beri başlamış, gelişerek günümüze kadar uzanmıştır. Müziksel düşünceler doğanın sunduğu malzemeye insan aklının ve anlatım gücünün eklenmesiyle yetkinleşmiştir (Anton Webern, Yeni Müziğe Doğru, Çev. Ali Bucak, Pan yayınları, İstanbul, 1998: 22).

Felsefe, sanatı evrensel bir yaratım biçimi olarak algılamıştır. Estetik tartışmalarında sanat; yalnızca güzelliğin öznesi olarak değil, aynı zamanda yaratımın öznesi olarak kabul edilmiştir. Sanatın evrenselliğine ilişkin ilk tezler felsefede ileri sürülmüştür. Müzik felsefesi açısından müziğin evrenselliği 
şöyle açıklanmıştır: Müzik evrensel var oluşun temelinde yer alır ve düzenin oluşması için gereken uyumu, ritmi ve estetiği anlamaya yardımcı olur. Müzik yalnızca çalgılar tarafından icra edilen bir sanat dalı değildir. En önemli müzik aleti insanın kendisidir. Evrenin temelinde ses, ritim, ton ya da başka bir deyişle bütünüyle müzik vardır (Sufi Inayat Khan, insan ve Evren Arasındaki Köprü, Müzik, Arıtan Yayınevi, çev. Kaan Ökten, Tuğrul Ökten, İstanbul,1994: 11-12).

İnsanın yapısının ve davranışlarının biçimlenmesi konusunda iki temel görüş vardır. Bunlardan ilki, çevrenin insanı belirlediğini varsayar. ikincisi ise insanın çevresel etkilere rağmen yine de kendi kendisini belirleyebileceğini öne sürer. insanın kendi kendisini belirleyebilmesi, çevreye dair bilgilerini kullanabilip bu bilgiyi kendi dünyasını zenginleştirmede kullanmasıyla mümkündür. Bu bilgi her zaman somut yararcı bilgi değildir. Bazen duygulara, bazen heyecanlara, bazen de inançlara yönelik bilgiler kendimizi oluşturmamıza yardımcı olur. Müzik insanın kendisini oluşturmasına yardımcı olan önemli bir bilgi biçimidir (Sufi Inayat Khan, insan ve Evren Arasındaki Köprü, Müzik, Arıtan Yayınevi, çev. Kaan Ökten, Tuğrul Ökten, İstanbul,1994: 62).

Sanatın evrensel değerlere sahip olması ürünün statik, değişmez kuralları içermesi anlamını taşımaz. Sanat tarihi boyunca yaşanan dönemler ve bu dönemlerin insan üzerindeki etkileri bağlamında sanat sürekli değişim ve dönüşüm yaşamıştır. Bu değişim ve dönüşüm içerisinde çok sayıda ekol ve estetik kuram üretilmiş, bu kuramlar sanatçının farklı sanat söylemleri kullanmalarına neden olmuştur. Ekollerin yarattığı üslup farklılığı gibi, sanatçının yaratıcılığının belirlediği özgün seçki de sanatta ürünün dilini belirler. Bu nedenle genel evrensel estetik kurallarının ışığında her sanat ürünü sanatçısına bağımlı olarak özgün bir anlatım dilini yansıtır. Bu dil, estetiğin inceleme alanları içinde yer almış̧ır. Tüm sanatlarda olduğu gibi müzikte de değişik kalıplar ya da ortak anlatım biçimleri vardır. Bunlardan her biri bir temayı bir başkasına göre daha yakın ya da daha yatkın işleyebilirler. Bir bestecinin sonat biçimi altında anlattığını senfoni biçimi altında anlatmayacağı düşünülebilir. Ortak bir tema için bir besteci senfoniyi kullanırken diğeri bir sonat biçimini kullanabilir. Kalıplar ve anlatım biçimleri sanatçının seçimi olduğu kadar tüketicinin de seçimi ile ilişkilidir. Bir müzik alımlayıcısı aşk temasını senfonik formda dinleyebildiği halde ve estetik zevk aldığı halde opera formundan hoşlanmayabilir. Bu ayrım estetik kurallarla tanımlanmamalıdır. Bu ayrım estetik eğitim ve estetik eğitimin insan yaşantısında yarattığ zengin seçkiyle açıklanabilir (Avşar Timuçin, Estetik, Bulut yayınlan, İstanbul, 2002: 176).

Müzik hakkında düşünmek, kuramlar üzerine yoğunlaşmak, aralarında belli bir analoji kurarak bunu ontolojik boyutta sorgulamak demektir. Müziğe ilişkin kavramları açıklamak, çözümlemek, çerçevelerini belirlemek felsefeyle değil, müzik felsefesi ile olanaklıdır (Vural Yıldırım, Tarkan Koç, Müzik Felsefesine Giriş, İstanbul, 2006: 17).

Felsefenin temel kavramlarından biri olan gerçeklik; sanat felsefesinin ve estetiğin de sorunsalı olmuştur. Sanatta gerçeklik kavramının çeşitli ekollerin doğmasına neden olduğu gibi, sanatın gerçekliği de tüm felsefi dönemlerde tartışılmıştır. Bilim karşısında sanat, gerçeklik boyutunda karşılaştııılmış, bilimin nesnel gerçekliğine karşın sanatın daha karmaşık olan öznel gerçekliği her dönemde irdelenmiştir. 
Sanat gerçekliğin özgün sunumlarını içerir. Gerçekliğin yoğun bir biçimde yansıdı̆̆ı sanat yapıtı, gerçeklikle ilgili kaba görünümleri değil, gerçekliğin özgün yorumunu ortaya koyar. Sunumla gerçeklik arasında kökel bir bağ vardır. Görünüşleri ayrı da olsa özleri bir olan bu iki şey bilinçte ya da duygu ve düşünce dünyamızda birbiriyle buluşur. Bilinç gerçeklikten giderek yapıtı kurarken onu gerçekliğin anlamıyla benzer biçimde oluşturur. Sanat yapıtını, gerçekliği açıklamak üzere gerçeklikten süzen ya da damıtan bir bilincin gücü oluşturur. Bilinç yapıta güçlü ve yoğun bir anlam kazandırabilmek için onu özgün bir yapıya kavuşturur. Gerçeklik ve gerçekliğin sunumu özdeş iki gerçekliktir, ama iki ayrı gerçekliktir aynı zamanda (Avşar Timuçin, Estetik, Bulut yayınlan, İstanbul, 2002: 227).

Sanatın nesnel açıklamalara götürülmesindeki güçlük estetiği karmaşık bir edime götürür. $\mathrm{Bu}$ karmaşık edim onu çeşitli kılar. Çeşitlilikte kurulmuş olan yapıt tüketicisine çeşitli anlamlar ve görünümlerle ulaşır. Bu nedenle estetikte kesin kurallar belirlemek olanaksız ve gereksizdir (Avşar Timuçin, Estetik, Bulut yayınlan, İstanbul, 2002: 229).

Tüm insan üretimlerinde olduğu gibi sanat ta felsefede bir özne-nesne diyalektiğine dayalı olarak açıklanır. Sanatın diyalektiği felsefe tarihi boyunca çeşitli teorilerle tartışılmış ve diyalektik ilkeleri günümüzde bütünüyle belirlenmiştir: Sanat bir iletişim diyalektiğine dayanır. Sanatçı ürün yoluyla alımlayıcıya bir anlatıyı iletirken alımlayıcı onu algıladı̆̆ı oranda bir beğeni ya da tepki sunar. Sanatçı bu beğeni ya da tepkiyi eş zamanlı olmasa bile süreç içinde ürününe gösterilen ilgi ya da ilgisizlikten haberdar olur. Bu bilgi onun yaratacağı yeni üründe önemli rol oynar (Aziz Çalışlar, Gerçekçilik Estetiği, D yayınevi, İstanbul, 1986: 266).

Felsefedeki gelişmişlik uygar toplumlarda düşünsel tartışmaların yoğunluğunun göstergesidir. Dünya tarihinde büyük uygarlıklar önemli felsefi dönemler yaratmışlardır. Antik Yunan, Antik Çin ve Antik Roma büyük felsefi dönemlerin ilk mimarları olmuştur. Günümüzde felsefeye ilişkin tüm çalışmalar, sayılan önemli dönemlerin birikimleriyle biçim almıştır. Felsefe, yazılı kültür yoğunluğu olan uygarlıklarda gelişme olanağı bulmuştur. Ancak bizim toplumumuzda sözlü kültür özelliği ve İslam kültürünün olumsuz sınırlamaları felsefenin gelişmesini engellemiştir. Ülkemizde felsefe çoğunlukla “entelektüel vakit kaybı” olarak görülmüştür. Cumhuriyet dönemi sonrası felsefenin önemi fark edilmiş, bu alanda bilimcilerin yetişmesi sağlanmıştır. Ancak felsefe alanında yapılan çalışmalar toplumsal anlamda felsefenin algılanışını değiştirmeye yetmemiştir. Sanat felsefesi ise küçük bir ayrıntı olarak, çok sınırlı aydın tarafından önemsenmiş, eğitim sistemi içinde bile bütünüyle yer alamamıştır. Türkiye 'de müzik felsefesi alanında uzmanların yetiştirilmemiş olması çok yönlü bir yaklaşımla irdelenebilir. Okullarımızdaki felsefe öğretmenlerimizin yetersizliği, toplumda değer verilen bilimler arasında sayılmaması felsefecilerin sayısını azaltırken müzik alanında da büyük bir boşluk yaratmıştır. Müzik alanındaki boşluğun en köklü nedeni ise; felsefeyle, anlamlı ürünler verebilecek düzeyde ilgilenen müzik insanlarının ortaya çıkmamasıdır. Felsefenin çalışma alanları içinde müziğe en yakın alan estetiktir. Ülkemizde estetik çoğunlukla müzik alanları dışında düşünülmektedir. Oysa çalgı öğretiminin düzeyi yükseldikçe, derslerde daha çok müzikaliteye ve yoruma yer verilmektedir. Estetiksel davranışların temeli ise tekniktir. Seslendirilenlerde tekniğin doğru seçimi ve bu seçimin besteciye, 
dönemine ve çalınan esere uygun bir renkte kullanımı, eserdeki felsefi anlama yönelik uygun ses renklerinin elde edilmesi müziğin sanatsal kalitesini gösterir. Teknik yetkinlik estetik ve felsefi anlamdan yoksun kalınca tamamlanmamış ve ruhsuz bir icradan öteye geçemez. Bu nedenle müzik eğitimi özellikle ileri çalgı eğitimi teknikleri düzeyinde felsefe ve estetik eğitimine ihtiyaç duyar. Müzik insanda bir tür sesle düşünmek demektir. Düşünmeyi öğrenmeden sesi öğrenmek kuşkusuz yeterli değildir (Vural Yıldırım, Tarkan Koç, Müzik Felsefesine Giriş, Bağlam Yayınları, 3.Baskı, İstanbul, 2006: 10).

Müzik estetiği müziğin bireyler ve toplum için güzellik ve beğeni serüvenine yönelik çalışır. Eserlerin yapısına ve anlamına göndermelerde bulunarak kompozitörün yaratma sürecine katkı sağlar (Vural Yıldırım, Tarkan Koç, Müzik Felsefesine Giriş, Bağlam Yayınları, 3.Baskı, İstanbul, 2006: 27).

Yukarıda yer alan alıntıda da özetlendiği gibi akademik eğitim sistemimiz içerisinde felsefenin yer almaması müzik felsefesinin geliştirilmesinde olumsuz rol oynamış, gerek müzik insanı gerekse müzik beğenisine sahip nitelikli dinleyici kitlesinin yetiştirilmesinde düşünsel boyut eksik kalmıştır.

\subsubsection{Müziğin Sosyolojik Boyutu}

Sanat, bireysel üretim biçimi ve dili olmasına karşın, gerek tüketimi gerekse insanlarda yarattığ1 değişim ve dönüşüm nedeniyle toplumsal niteliğe sahiptir. Müzik ise diğer sanatlar içerisinde toplumsal bağları en güçlü olan sanattır. Müziğin tüketilmesinin toplumsal yapılanması bütünüyle sosyolojik bir olgudur. Aşağıda sosyolojik açıdan müziğin algılanışına çeşitli bakış açılarıyla ve boyutlarıyla yer verilmiştir. Müziğin insan davranışlarını yönlendirme ve yönetme gücü kitlelerde ortak bilinç oluşturmayı sağlar. Müziğin duyusal, bilişimsel, davranışsal etki gücüyle birçok yeni davranış oluşturulabilir. Müzik eseriyle toplum arasındaki etkileşim siyasetten eğitime, zorla kültürlenmeden yabancılaşmaya, etnik yapıdan ulusal yapıya dek uzanmaktadır (Ayten Kaplan, Kültürel Müzikoloji, Bağlam Yayınları, İstanbul, 2005: 113).

Sanatın toplumsal boyutu, toplumsal bir olgu olan kültürel boyutunu da belirler. Sanatın toplumsal ilişkileri, toplumların yapısı ve aynı toplum içindeki toplumsal kimliklere göre farklılıklar gösterir. Toplumun içinden geçtiği özel dönemler ve toplumsal olaylar müziğe yansır. Kültürel alışkanlıkların ve ritüellerin de müziğin tüketilme biçimini belirlediği söylenebilir. Müziğin toplumsal yapı içindeki konumu şöyle değerlendirilebilir. Sanat, gerçek yeniliği sunduğu zamanlarda aslında zaten paylaşılan yaşantının ifadesi ve simgesini vermiş olduğunu görürüz. Yeni olan, yaşama verilen yeni anlamdır. Toplumların içinde bulunduğu kritik dönemler sanatta buluşmayı yoğunlaştırır. Böyle dönemlerde sanat, kolektif bir anlatım biçimine dönüşür. Örneğin özel dönemlerde belli müziklerin marş gibi seslendirilmesi, ya da belli melodilerin belli anlamları simgelemesi sanatın anlatım zenginliğinden kaynaklanır. Ancak sanatsal kültürü yoğun birikimlere dayalı olan kültürlerde bu toplumsal anlatım bir tür kolektif sanat üretimine dönüşürken bu birikimden yoksun olan ülkelerde bu dönemler değersiz moda üretimlerini yaratır (Ken Baynes, Toplumda Sanat, Çev.Yusuf Atılgan, Yapıkredi Yayınları, İstanbul, 2002: 215). 
"Her çeşit sanat toplumun bireyi onun eylemlerindeki anlamı yorumlamasına katılır. Her toplumda sanatın dili büyük bir uyum içinde değildir. Karşıtlıklar ve çatışmalar içerir. Sanattaki bu karşıtlıklar ve çatışmalar aslında toplumun içindeki karşıtlıklar ve çatışmalardan oluşur. Sanatın içeriği, biçemi, bağlı bulunduğu ekolü ne olursa olsun toplumsal yapı içinde bir taraftır. Gerek ekonomik katmanlaşmalar, gerekse iş bölümüne dayalı toplumsal statüler üretilen ve tüketilen sanatı aynı toplum içinde çeşitlendirir. Sanat, toplumda yaşayan bireylerin yaşamlarını etkilediği gibi, toplum da sanatın içeriğini ve işlevini belirler. Doğal olarak sanat eğitiminden beklentiyi de çoğunlukla toplum belirlemektedir. Toplumla devlet kurumu arasında farklar olduğu zaman devlet, eğitimini ve içeriğini belirler ama bu eğitim ve içerik toplumun gerçekliğiyle çelişir (Ken Baynes, Toplumda Sanat, Çev.Yusuf Atılgan, Yapıkredi yayınlan, İstanbul, 2002: 28).

Sosyoloji, müziği irdelerken diğer sosyolojik kavramlara yaklaşım biçimiyle ele alır. Müziğin estetiksel ve yaratımsal yanıyla özel anlamda ilgilenmez. Sosyolojinin müziği ele alış biçimi şöyle özetlenebilir: Sosyolojinin ve müzik sosyolojisinin fonksiyonlarım söyleyebilmek için, genelde bilimin fonksiyonlarının neler olduğuna bakmak gerekir. Betimleme, açıklama, yordama, denetleme, yayma, izleme, bilim insanlarının kısıtlanmış ve maddeleştirilmiş olan bilim fonksiyonlarını yerine getirmeye çalıştığı alanlardır (Edip Günay, Müzik Sosyolojisi, Bağlam yayınları, İstanbul, 2006: 27).

Müzik sosyolojisinin fonksiyonları: bireysel ya da grup olarak müzik kuruluşları ile diğer kültürel değişkenler arasında ilişkileri bulmaktır. Aynı zamanda, toplumsal olaylarda müzik değişkenini aramak, ülke genelinde müzik çeşitlerine yönelişleri ve bunların nedenlerini araştırmak, müzik kurum ve kuruluşlarına ilişkin araştırmalar yapmak, göç, gelenek, toplum, cemaat vb. gibi toplumbilimin temel kavramlarının müzikteki yankılarını bulmak müzik sosyolojisinin sorunları arasındadır (Edip Günay, Müzik Sosyolojisi, Bağlam yayınları, İstanbul, 2006: 31).

İnsan sürekli değişen bir varlık olarak kültürünü ve doğal çevresini değiştirir. Müzik toplumbilimi de tarihsel süreç içinde ele alınarak incelendiğinde bu değişime müziğin katkısını izler (Edip Günay, Müzik Sosyolojisi, Bağlam yayınları, İstanbul, 2006: 32).

Müzik sosyolojisinin bireysel katkıları sosyal-psikoloji açısından önemlidir. Gesthald anlayışımızı üç başlık altında topladığımızda müzik sosyolojisinin bireysel ya da sosyal psikolojik öğeleri şöyledir:

a) Müzik sürecinin içsel örgüsü: Müzik yaratısını oluşturabilmek için kullandığımız tüm müziksel değişkenleri düşünmeliyiz. Biçim, belli çalgılar kullanılarak renklendirilmiş sesler, bu seslerden oluşan ezgi çizgileri ve çok seslilikler gibi. Besteci bu müzik yapım gereçleri içinden seçimler yapıp onları birleştirerek bir müziksel kurgu oluşturur. Bestecinin görevi bu kurguyu sanat düzeyinde oluşturmak, seslendiricinin görevi ise estetiksel seslendirmenin ötesinde, yaratının gizil güçlerini ve anlamlarını dinleyiciye sezdirmeye çalışmasıdır. 
b) Müzik yaratısının süreçleri: Müzik yaratısı belli bir zaman ve mekanda başlar ve biter. $\mathrm{Bu}$ sınırlar içinde düşünülen yaratının yalnızca kendisiyle ilgili olan küçük bir bölümüdür. Müziğin başlangıcının daha öncelerde olduğunu anımsatıcı; giriş, giriş akoru, giriş anlamında bir bölüm besteci eliyle konulabilir. Bazı yaratılarda ise yaratının orada verilmeyen başlangıcının olduğunu sezdiren ilk ölçünün başında başlamayan kurgulara rastlarız. (Bach'ın bazı yaratılarının başında olduğu gibi). Yaratıların bireyleri ilgilendiren öncesi ile yaratı izlendikten sonra bireylerde süren etkileri de düşünülmelidir. Bu bizi müzik yaratılarının yalnızca seslendiricilerden dinlediğimiz kadar kısa ya da uzunca yaşam süreci olmadığını gösterir.

c) Müzik yaratısının mekanı: Müzik yaratısının asıl mekanı sessizliktir. Mekandan kastedilen yaratının yeniden yaşam bulduğu ortamdır. Çevresel koşullardaki müzik dışı etkenler müziği algılamamızda ve ondan etkilenme düzeyinde değişiklikler otaya çıkarır. Psikolojiyle müzik sosyolojisi arasında bu boyutta da bir ilişki vardır (Edip Günay, Müzik Sosyolojisi, Bağlam yayınlan, İstanbul, 2006: 86).

Sanatın toplumsal ilişkileri, toplumun içinde bulunduğu tarihsel koşullar bağlamında farklılıklar gösterir. Toplumsal yapıların yönetim biçimleri ve yönetim yapılarının ideolojik yaklaşımları bir üst yapı kurumu olan sanatı doğrudan etkilerken müzik de bu etkilenmenin kapsamı içindedir. Toplumun sınıfsal, ekonomik, siyasal çelişkileri ve çatışmaları müziğe doğrudan yansır. $\mathrm{Bu}$ yansımalar, sosyolojik araştırmaların alanına girdiği gibi ülkelerin kültür politikaları anlayışlarıyla da yakından ilişkilidir. Sanat günümüzde teknolojik gelişmelere bağlı olarak toplumsal yaşamın tüm alanlarına etkili bir biçimde girmiştir. Sanatın insanlık tarihi boyunca yerine getirdiği farklı toplumsal işlevleri, çağımız teknobürokratik toplumlarında gittikçe politize olmaya başlamıştır. Bu politizasyon olgusu, özellikle sanatın geleceğe ışık tutması, geleceğe yönelik fikirleri taşımasının doğal bir sonucudur (İbrahim armağan, Sanat toplum bilimi, İleri Yayınları, İstanbul, 1992: 2).

Sanatın gelişmesinde tarihsel-toplumsal koşulların önemli bir etkisi olmasına karşın, sanatın gelişmesini sadece bu koşullarla açıklamak yeterli değildir. Birer üst yapı ürünü olan sanatsal ürün ve etkinlikler, düşünce, duygu ve aklın ortak ürünleridir. Özgür düşünce, bilimsel tutum, sanatsal yaratının temel koşullarıdır. Bu nedenle özgürlükçü demokrasilerin egemen olduğu toplumlarda sanatın daha hızlı gelişip yaygınlaştığı ve sanatın daha kolay toplumların günlük yaşamına girdiği görülmektedir (İbrahim armağan, Sanat toplum bilimi, İleri Yayınları, İstanbul, 1992: 3).

Çağımızdaki değişme ve gelişmeler sonucu oluşan yoğun ekonomik bunalım ve dengesizliklerin yaşanıldığı dünyamızda her şey hızla değişmektedir. Kitle iletişim araçları ülke sınırlarını giderek saydamlaştırmıştır. Artık günümüzde herhangi bir toplumsal olgunun başka bir topluma aktarılmasını engellemek, hemen hemen olanaksızdır. Bu nedenle dünyanın herhangi bir köşesindeki sanatsal üretim biçimi çeşitli dönüşümlere uğrasa da, hızla dünyanın diğer bölgelerine yayılabilmektedir. Sanatın toplumsal kimliği ve niteliği toplumun uygarlaşma niteliğinin de göstergesidir. Toplumların birbiriyle ilişkilerinde sanat yoluyla kültürel egemenlik kurma, çağımızın önemli sömürü alanlarından biridir. 
Sanatın toplumsal değişim gücünü fark edemeyen az gelişmiş yapılar, güçlü toplumsal kimliklerin ürettiği kültürel bilgi ve ürünleri sorgulamadan tüketir. Bu durum dolayımlı bir sömürülme olgusunu yaratır. Kültürel emperyalizm olarak da adlandırılan, kültür yoluyla diğer toplumu egemenlik altına alma modern savaşların bir yöntemidir. Bu yönteme karşı direnebilmek için güçlü kültürel, sanatsal ve bilimsel bilinç gereklidir. Sanat sosyolojisi boyutunda bu olgu şöyle değerlendirilmektedir: Bilim ve sanatı ortaya koyan bilimsel etkinlik toplumların kendine güvenlerini artıran önemli bir güçtür. Bu gücün diğer toplumlar üzerinde egemenlik aracı olarak kullanılması bütün güçlü ülkelerin devlet politikalarının kapsamında yer alır. Sanat toplumbilimi, bir başka deyişle sanat sosyolojisi sanatın gücünün toplum yararına kullanılma yöntemlerini açımladığı gibi aynı zamanda sanat yoluyla gerçekleştirilen kültürel egemenlikler karşısında nasıl güçlü olunabileceğinin bilincini yaratır. Sanat toplumbilim konusunda ilk önemli çağdaş yaklaşımlar George Lukas tarafından geliştirilmiştir. Onun görüşleri Adorno, Walter Benjamin, Goldmann tarafından geliştirilmiştir. Geliştirilen bu toplumbilim teorisine göre bir toplumsal yapının sanatsal eylemlerine ve ürünlerine bakarak o toplumun içinde bulunduğu toplumsal problemleri ya da toplumsal gelişmişliği görmek olasıdır. Ya da tersine toplumsal problemleri analiz ederek bu toplumun sanatsal potansiyelini tespit etmek olasıdır (İbrahim armağan, Sanat toplum bilimi, İleri Yayınlan, İstanbul, 1992: 7).

Çağımızın teknolojik toplumlarında toplumsal yapılar karmaşık ilişkilere dayanır. Yabancılaşma, kimlik bunalımları, eklektik kültürel yansımalar sanatsal tutum ve davranışlara da yansımaktadır. Toplumdaki ekonomik çelişkiler, siyasal baskılar bir aydın grubu olan sanatçıyı ve onun yaratımlarını kolayca etkiler. Bu etkilenme her zaman bir karşı çıkış ya da başkaldırı tutumu değildir. Zaman zaman itaat, içe kapanma ve sorunlardan uzaklaşma biçimiyle tepki yaratabilir (İbrahim armağan, Sanat toplum bilimi, İleri Yayınlan, İstanbul, 1992: 20).

Bilgi toplumbilimi açısından sanat ve bilim toplumsal bilincin bir öğesi ya da türüdür. Gerek bilim gerekse sanat gözlemler ve deneyimlerle geçirilen bir süreçte olgunlaşır. Önemli olan bu sürecin algılanıp verimli geçirilmesini sağlayacak bilincin gelişmesini gerçekleştirmektir. Bilim ve sanatta artık sınırlar ortadan kalkmak üzeredir. Sanatı insanlık yararına kullanabilmek için bilime; bilimi gelecek dünyanın insanına ulaştırabilmek için sanatsal düşünmeye ihtiyaç vardır (İbrahim armağan, Sanat toplum bilimi, İleri Yayınlan, İstanbul, 1992: 24).

Müziğin toplumsal yapılarla sıkı iletişimi, toplumsal beğeniden etkilenmesini yaratır. Tüm sanatlarda olduğu gibi müzik sanatında da beğeni düzeyleri ve seçkileri toplumun her kesiminde farklı özellikler taşır. Müziğin kolektif tüketim değerleri gündelik hayattaki seçkilerin hızla yayılmasını ve kitleselleşmesini sağlar. Sanatta popülerleşme, çoğunlukla bozulma olgusu olarak algılanır. Ancak bu olgu kaçınılmazdır. Müzik toplumun büyük bir kesiminde popüler beğeniye seslenirken, bu beğeniden etkilenmeyen müziği estetik değerleriyle benimseyen küçük de olsa bilinçli sanat tüketicisi grubu her zaman vardır. Sanatın estetik sürekliliğini bu grup sağlar. Sosyoloji sanatın popüler kültür içindeki rolünü ve etkilenme biçimlerini inceler, değerlendirir ve sonuçlarını saptar. Müzik sosyolojisi de aynı bilimsel yaklaşımla popüler müzik seçkilerine sosyolojik bakış açısı getirir. Bu bakış açısı şöyle özetlenebilir: Popüler, başlangıçta Latince "popülaris" ten türeyerek "halka ait" anlamına gelen siyasal bir terimdi. 
Örneğin 16. yüzyılda kullanılan popüler hükümet terimi, halk tarafından kurulan ve yürütülen bir siyasal sistem anlamına geliyordu. Günümüzde de popüler vurgu yine genel olarak "halka" gönderme yapar. Halkın genel beğenisinin adlandırılmasında "popüler" kavramı kullanılır. Ancak günümüzde "popüler", halkın seçimi değil de daha çok kitlelerin edilgen tutumunu anlamlandırır. Günümüzde "popüler" halka aittir ama halkın seçimi değil, halka sunulanı gösterir (Ayhan Erol, Popüler Müziği Anlamak, Bağlam Yayınları, İstanbul, 2005: 43).

Popüler müzik birçok dünya görüşü tarafından farklı tanımlanmıştır. Bu tanımlamaları gruplarsak, 1. Normatif tanımlama: popüler müzik bayağı bir türdür. 2. Olumsuz anımlama: popüler müzik folk ya da sanat müziği olmayan müziktir. 3. Toplumbilimsel tanımlama: popüler müzik belli bir toplumsal grup ile ilişkilidir. Alt sınıfların ürettiği müziktir. 4.Teknolojik-ekonomik tanımlar: popüler müzik kitle medyası tarafından üretilip pazarlanan müziktir. Bu 4 kategorideki tanımların hiçbirisi popüler müziği doyurucu olarak tanımlamaz. Her biri popülaritenin bir yönüne vurgu yapmıştır gösterir (Ayhan Erol, Popüler Müziği Anlamak, Bağlam Yayınları, İstanbul, 2005: 81).

Halkın seçimine dayandırılan "popüler" kavramının müzikte günümüzde iletişim teknolojilerinin ve medyanın da toplumun beğenisini etkileme gücüyle daha çok endüstrinin öne çıkardığı ve rant yaratabilen sunumları temsil ettiği söylenebilir. "Yeryüzünde popüler müzik olarak kategorize edilecek tüm müziklerde insanların müzik dinleme alışkanlıklarını daha çok kaydedilmiş ürünlere dayandırdığı ve buna bağımlı bir dinleti alışkanlığının geliştiği söylenebilir. Popüler müziğin bugünkü formu teknoloji olmaksızın korunamaz. Dolayısıyla müzik endüstrisinde yeniden üretilen ve kitle medyasınca yayılan popüler müzikler, sosyo-kültürel bir doğumun, büyümenin, gelişmenin, değişmenin ve bunu gösteren bir sürecin ürünüdür gösterir (Ayhan Erol, Popüler Müziği Anlamak, Bağlam Yayınları, İstanbul, 2005: 88).

Popüler müzik, popüler öncesi durum ve bu durumu oluşturan gerecin popülerleşme sürecindeki işlenişine dayanır. Muğlâk bir alt-kültür ya da kolektif bir kültürel kimlikle beliren her kültürel yapı söz konusu "özgül külttürel çevredeki popülerin " dışına çıkma potansiyeline sahip bir popüler gerece sahiptir. Her popüler müziğin özgül koşullardaki inşa sürecinde "öteki unsurlarla" fiili ve söylemsel ilişkinin nasıl kurulduğu belirleyici bir öneme sahiptir (Ayhan Erol, Popüler Müziği Anlamak, Bağlam Yayınlan, İstanbul, 2005: 103).

Uluslararası müzik endüstrisinin kendi amaçları doğrultusunda tüm toplumların dinleyeceği ya da izleyeceği türdeş ürünler yaratmaya yönelmesi, birbirinden farklı uzlaşmalarla oluşturulan popüler müziklerin birbirleri arasındaki sınırları giderek zayıflatır. Ancak bunların tümü, zorunlu bir homojenleşme ile sonuçlanan süreçler değildir. Benzer etkilerin evirdiği bir türdeşleşmeden söz edilebilir. Yapısal özelliklerini egemen ya da başka popüler müzik üslupları ile uzlaştırmak üzere değişikliğe uğratmak için bir popüler müzik ve izler kitlesi üzerine baskı uygulanabilir. Ancak bu baskı ne kadar artarsa kendi anlamlarını yeniden üreterek yeni sınırlar ortaya koyma eğilimini yaratır. Yani popüler müziklerin inşa edilip, birbirleriyle kaynaşıp yeniden ayrışması popüler kültürün kaçınılmaz özelliğidir (Ayhan Erol, Popüler Müziği Anlamak, Bağlam Yayınlan, İstanbul, 2005: 142). 
Müzikte popülerleşme, kendini küçük kitlelerin beğenisinden kurtarıp daha büyük kitlelerin beğenisine ve tüketimine kabul ettirmesiyle gerçekleşir. Burada yaratılan eserin pazarlanmaya çalışılmasından çok, pazarlanabilecek eserlerin ortak beğeni kalıplarına uygun olarak üretilmesi söz konusudur. Bu ortak kalıplar ise kültürel kimliklerin dışında daha geniş bir kitlenin beğenisini oluşturan kalıplar sayılabilir. Buna karşın popüler müziklerde, hedef kitlelerin kültürel kimliğine dayalı ezgilerin de yer aldığına sıklıkla rastlanabilmektedir. Popüler müzik anlamı çözümlemesinde kültürel kimliklerin önemli bir inceleme alanı olduğunu bilmek kaçınılmazdır. Bir popüler müzik türü, bir pop şarkısının ezgisi, sözleri ya da tümü olarak içeriği, yorumcudan dinleyiciye gönderilen bir ileti olmasından ötedir. Yorumcu; müzik endüstrisi, teknolojisi, medya ve dişsal etkilerle ve bu etkilerin belirleyicilikleriyle iletisini sağlar. Dolayısıyla bu iletide salt yorumcunun söylemi yoktur. Sayılan diğer aracıların her biri iletiye kendi açısından katılır. Alımlayıcı açısından da durum yalın değildir. Alımlayıcı kendisine sunulan iletiyi bağlı olduğu kültürel kimliğin kolektif aidiyetine göre algılar. Dolayısıyla popüler müzikte yorumlayıcı ile alımlayıcı arasında sayısız etken vardır (Ayhan Erol, Popüler Müziği Anlamak, Bağlam Yayınlan, İstanbul, 2005: 150).

Mümkün olan en çok insana ulaşma amacı ile yola çıkan bir endüstriyel popüler müzik, izler kitlenin ayrışıklığ yüzünden kendisini ortaya koyduğu andan itibaren kültürel anlamdaki biriciklikten çok kendisini genellemelerle sunmak çabasındadır. Umberto Eco'nun dediği gibi: “etkinin gerçekleşmesine yol açan biçimin değerlendirmesini işe karıştıran estetik haz kavramına, edimsel olarak başka bir anlam verilip verilmediği bir sorundur. Ancak kimi toplumlarda sanat, günlük yaşamla o denli derinden bütünleşmeler kurmaktadır ki, onun birinci işlevi artık elden geldiğince özel tepkilere yol açmak olur." Dolayısıyla geniş bir izler kitleyi hedefleyen popüler müzik, kullanacağı kodlarda (şarkı sözü, ezgi, ritim, çalg1 vb.) izler kitlenin uzlaşım ya da kültürel deneyim çeşitliliğine kendisini uydurmak gayretindedir. Sonuç olarak yetenekli müzisyenler popüler müzik ürünlerinde becerilerini yansıtabilir ve bunlar müziğgin içsel özellikleri olarak onların izler kitleleri tarafından algılanabilir. Seslendiricilerin ya da popüler müzik izler kitlesinin nitelikleri üzerine bütünüyle gerçekçi bir analiz yapmak olanaklı değildir. Ya da hiç değilse estetik gerekçelendirme bulmak zordur (Ayhan Erol, Popüler Müziği Anlamak, Bağlam Yayınları, İstanbul, 2005: 170).

Popüler müzik tüketicisinin beğeni beklentilerini sınırlandırmak olanaksız görülmektedir. Günümüzde kitle iletişiminin evrenselleşmesi boyutu da, kitlelerin söz konusu kültürel öğelerinden de bağımsız bir müzikal yapıyı popüler müzikte göz önüne sermektedir. Ayrıca popüler müziklerin müzikal yapısının yanı sıra görsel birçok sunumu da içermesi, bu müzikal yapının değişkenliğini yaratmaktadır. Popüler müzik tüketicisinin beklentisi o müziğin, toplumun tarihsel birikimine dair kültürel öğeleri içermesinden çok günlük tepkiler yaratması ya da bu tepkileri desteklemesi yönündedir. Müzik endüstrisi içi önemli olan kimin hangi müziği hangi açıdan nasıl anlamlandırdı̆̆ı değil, üretilen müziğin ve satışın ölçülmesidir. Popüler müzikte anlam üretimi, kültür ekonomisinde bu metayı kullananların popüler üretkenliklerinde yatmaktadır. Anlamlar yalnızca kültür denilen ve süreklilik arz eden bir süreçte üretilebilir, yeniden üretilerek dolaşıma sokulabilir (Ayhan Erol, Popüler Müziği Anlamak, Bağlam Yayınları, İstanbul, 2005: 204). 
Bilimsel müzik incelemelerinde bilgi, kuramsal bir girişim olarak sosyo-kültürel dünyada var olan müziksel düzenlilikleri keşfetmeyi ve böylece genellemelere varmayı hedeflemez. Çünkü her sosyokültürel dizgenin içinde yerleşik olan müziksel etkinlik özgül bir tasarımın ve simgeler sisteminin ürünü olarak tarihsel bir nitelik taşır. Bu tarihsellik müziksel ve popüler müzik ile ilgili oluşumların birbirine benzemediği, düzensizliği, genellemelere konu olmayışı anlamındadır. Bu durumda kuramsal bir çaba olarak popüler müzik incelemeleri açıklamaya değil anlamaya yönlenmek durumundadır. Popüler müzikte anlamı, bir kolektivitenin sınırları içinde üretilen bir ürün olarak ele alır. Bu yaklaşımla kültürel kimliği oluşturan, pekiştiren, dönüştüren birikimi anlamaya yardımcı olacak kavramsal çözümlemeler yapar ve bunların etken kullanıldığı bir kuramsal çerçeve önerir (Ayhan Erol, Popüler Müziği Anlamak, Bağlam Yayınları, İstanbul, 2005: 284).

Ülkemizde sanatın sosyolojik boyutu bilimsel kapsamda yeterince anlaşılamamıştır. Sıradan insanın bu bilinci taşımamasının yanında akademik anlamda da yeterince ele alınıp, veriler yaygınlaştırılamamıştır. Toplumsal olgu ve olayların analiz ve yorumları, dar kapsamda dünya görüşleri biçiminde algılanmaktadır. Eğitim sistemimizde de sosyoloji, ansiklopedik bilgi birikiminin ötesinde işlevsel boyutlarıyla yeterince yer almamaktadır. Sanat eğitimi veren kurumlarda da genel eğitim anlayışının daha sınırlı olarak benzeri yaklaşım görülür. Sanatın sosyolojik boyutu çok sınırlı olarak yüksek lisans programlarında yer alır. Müzik sosyolojisine yönelik çalışmalar ise daha da sınırlıdır. Sosyolojinin genel problemlerinden başlayarak müziğin sosyolojik özel alanlarına kadar çok sayıdaki önemli problem, eğitim sistemimizin tartışma alanına girememiştir. Durumu şöyle açıklamak olasıdır: Müzik alanında öne çıkan müziğin yapılması ve dinlenmesi olduğundan, onu anlamlandırmak, nedensellik ilişkilerini irdelemek ikinci plana itilmiştir. Kaynağından toplanan bilgiler (müzik eserleri) yalnızca eğitim ve seslendirme amaçlı kullanılmıştır. Bu da müziğin üretildiği ortam içinde (bağlam) anlamlandırılmasına yönelik çalışmaların yapılmasını zorunlu kılmıştır. Müziği araştırmak; toplumu incelemek, kültürü kodlamak, kavramsallaştırmak müzik üzerine söylem kurmak demektir. Örneğin kırdan kente oluşan göç olgusu bağlamında, türkülerin sosyo-politik değişim ve kullanım değerlerini, türkülerin varoşlarda kitle üzerinde yarattığı etkileri görmek ancak böyle bir incelemeyle olasıdır. Müziğin kültürel bağlarını incelemek için müzik araştırmaları müzik sosyolojisine ihtiyaç duyar (Ali Akay, Toplumbilim Dergisi, Müzik ve Kültürel Kimlik Özel Sayısı, Bağlam Yayınları, İstanbul, 2001: 8).

Bir bireyin kültürel değerleri içinde müziğe ilişkin değerlere müziko-kültürel değerler ya da onun müziko-kültürel kimliği diyebiliriz. Türkiye 'de çocuklar henüz okula başlamadan önce büyük ölçüde ailesinden ve bölgesinden kaynaklı olarak yerel kültürel değerlerle müzikle tanışır. Batılı müzik değerleri okulda tanıştığı değerlerdir. Son 30 yıla kadar yani Türk müziği konservatuarlarının müzik eğitimcisi yetiştirme süreçlerine kadar çocuk için müzik batı anlamında çok sesli müziğin kültürel değerleriydi. Giderek bu kültürel ikilem ortadan kalkmaya başlamış olmasına karşın bu kez de yerel müziğin müzik bilimleri birikimi olmaksızın yalnızca ulusal duygulanımlarla benimsetilmesine yönelik karşı bir kültürel bağnazlık başlatılmıştır. Eğitimde yakından uzağa, bilinenden bilinmeyene, ulusaldan evrensele giden bir çizgi izlenmelidir. Bu çizgi izlendiğinde çocuk ilk tanıdığı yakın çevresinin melodilerini irdeleyip anlamayı gerçekleştirdikten sonra giderek evrensel müziğin kültürel değerlerini, 
müziksel estetiğini, özellikle müziğin sınırsız olanaklarını anlamaya başlayacaktır. Müzik kültürel bir dışavurum eylemidir. Bu nedenle tüm müzik eğitimi süreçlerinde bireyin müziko-kültürel kimliğinin dışa vurulması, korunması, geliştirilmesi desteklenmelidir. Ancak, aynı zamanda müziğin evrensel birikimi de çocuğun algılama, kıyaslama, seslendirme yeteneklerine paralel olarak verilebilmelidir. Böylece çocuğun müziko-kültürel kimliği etnik sınırlardan evrensel genişliğe doğru yol alabilir (Gürsel Yurtseven, Toplumbilim Dergisi, Müzik ve Kültürel Kimlik Özel Sayısı, Bağlam Yayınları, İstanbul, 2001: 20).

Müzik eğitimi veren kurumların programlarında müziğin sosyolojik boyutu kapsamında, ulusal sanat değerlerinin de yeniden tartışılması gerekir. Müzik, eğitsel temelde farklı türlerde ele alınırken kendiliğinden toplumsal ayrışmalara da vurgu yapar. (Örn. halk müziği, sanat müziği gibi). Bu vurgunun doğru algılanması ve öğrenci bilincinde sanatsal niteliklerden ödün verilmemesi için toplumsal çoğunluğun beğenisini temsil eden türlerin diğer türler karşısında bir alternatifmiş gibi varsayılmaları engellenmelidir. Müziğin sosyolojik boyutunu algılamanın, bilimsel bilincin gelişmesini sağlayacağı gibi yanlış sanatsal önyargıların da ortadan kalkmasına yardımcı olacağı açıtır.

\subsubsection{Müziğin Kültürel Boyutu}

Müziğin sosyolojik boyutu bölümünde vurgulandığı gibi sanatın toplumsal ve kitlesel etkileme ve etkilenme özelliği onu toplumsal politikaların öznesi haline getirir. Çağdaş dünyada, ülkeler arası kültürel rekabetin arttığı bir ortamda toplumsal denge ve düzen arayışlarının kalıcı olması için doğru kültür politikalarının geliştirilmesi kaçınılmazdır. Sanat bu yönde en etkili kültür öğelerinden biridir. Bu nedenle kültür politikalarına ilişkin geliştirilebilecek hiçbir strateji sanatsal olgudan bağımsız düşünülmemelidir. Sanatın toplumda nasıl oluştuğunu, toplumun sanata nasıl etkide bulunduğunu sormaya değil, tersine toplumun sanat yapıtlarında kendini nasıl nesneleştirdiğini bilmek isteyen müzik sosyolojisi günümüzde önem kazanmıştır. Müzikte nesneleşen toplum artık müziğin gerçeğidir. Toplumsal gerçek değildir. Bu anlamda müzik sosyolojisi, ideolojik içerikle ve müziğin ideolojik etkisiyle ilgilendiği ölçüde, toplumun eleştirel bir öğretisi olur (Ömer Naci Soykan, Müziksel Dünya Ütopyasında Adorno ile Bir Yolculuk, Bulut Yayınları, İstanbul, 2000: 79).

Müzik, sanat ve tüm kültürel etkinliklerin bir iç içe geçişi ve bağlanışı anlamında, uygarlık ve politikadır. Bu politika kültüreldir. Toplumda müziğin içinde olduğu kültür üzerinde planlı ya da plansız gerçekleştirilen tüm etkiler müziğe yansır. Müzik birçok yüzyılda hem resmi kültürün yaptırımlarıyla hem de bölgesel ideolojik yaptırımlarla savaşmak zorunda kalmıştır (Ömer Naci Soykan, Müziksel Dünya Ütopyasında Adorno ile Bir Yolculuk, Bulut Yayınları, İstanbul, 2000: 80).

Müzik yaşama alternatif değildir. Ancak yaşamın sürüklediği bir yaratım biçimi de değildir. Müzik, estetik gerçekliğiyle toplumsal problemlerin çözümüne katkı sağlar, kendisi bir toplumsal probleme dönüştürülmez. Kültür politikalarının ve stratejilerinin belirlenmesi yönetsel sistemin temel sorumlulukları arasındadır. Demokratik parlamenter sistemlerde devlet adına konunun uzmanı olan bir düşünce takımı çeşitli disiplinlerde kültürel kimlik yansımaları projelendirir. Kültür ve sanat politikaları bütünüyle siyasetten ve günlük politikadan koparılamamaktadır. Bu olumsuz etkilenme, az gelişmiş 
ülkelerde istikrarsız yaklaşımların etkili olmasını, parti ideolojisinin devlet eliyle kültür politikalarına yansımasını getirir. Oysa modern Avrupa toplumlarında kültür stratejileri ve politikaları bütünüyle partiler üstü devlet mekanizmaları tarafından düzenlenir ve uzun erimli programlar günlük siyasetten etkilenmezler. Kültür politikalarının iki ayrı cephesi vardır: birinci cephe ulusal kimliğin dış dünyaya yansımasını belirlerken; ikinci cephe, ülke insanlarının kültürel düzeylerinin, uygar dünyanın düzeyine yaklaştırılabilmelerini sağlayacak bilinç oluşturma etkisini oluşturur. Eğer devlet bu sorumluğunu titizlikle yerine getiremezse, kolayca kültür piyasalarının tüketicisi haline gelecek toplumsal karmaşayla yüz yüze gelir. Sanatçının zihinsel kavrama ve yorumlama süreci, düşünce yapısının oluşturduğu kültürel ortamdan etkilendiği oranda, kültürel yapıya koşut yapıtlar ortaya çıkar. Kültürel yapı ile sanat eseri arasındaki ilgi, sanatçının öznel değerlerinin toplumsal ölçütlerle örtüştüğü dönemlerde daha belirginleşir. Değerlerin örtüşmesi ise ortak amaç çatısı altında bileşildiği anlarda söz konusu olur (Nilüfer ÖNDİN, Sanat Dünyamız, sayı 89, Yapıkredi yayınları, İstanbul, 2003: 154).

"Ülkemizde cumhuriyetin kuruluş yıllarından itibaren sanatın yeni olarak sunulan dünya görüşünü kitlelere ulaştırmak misyonunu yüklenmesi, kültür politikası sanat etkileşiminin itici gücü olur. Cumhuriyetin modernleşme bağlamında toplumun formasyonunu hedefleyerek rasyonellik üzerine temellenen devlet merkezli bir toplum oluşturma girişimi sanatın ulusal bir kültür politikasına hizmet etmesi için yönlendirilmesini sağlamıştır (Nilüfer ÖNDİN, Sanat Dünyamız, sayı 89, Yapıkredi yayınları, İstanbul, 2003: 155).

Cumhuriyetin kuruluş yıllarında ulusal sanat politikası sanat eğitimcileri yoluyla bütün ülkede benimsetilmesi doğrultusunda programlanmış, bu dönemde gerek müzikoloji alanında gerekse Türk Müziğinin notalandırılması çalışmalarında önemli rol kat etmiştir. Özellikle sivil eğitim kurumları olan halk evleri yoluyla modern Türkiye 'nin müzik anlayışı önemli ölçüde geliştirilmiştir. Bu çalışmalar sanatı himaye eden devletçilik anlayışıyla gerçekleşebilmiştir. Ancak bu çaba uzun sürmemiş, 1940’lardan sonra kültür ikinci plana itilmiş, dolayısıyla da ihmal edilen sanat eğitimi içinde müzik eğitimi de toplumsal gelişimini eğitim açısından durdurmuştur (Nilüfer ÖNDİN, Sanat Dünyamı, sayı 89, Yapıkredi yayınları, İstanbul, 2003: 155).

Ülkemizde özellikle 1970’lerden sonra yaşanan hızlı toplumsal değişimler, üretim tüketim ilişkilerindeki kapitalistleşme süreci ve ekonominin bireyler üzerindeki belirleyici etki ve arayışları kültürel yapıda ciddi olumsuzlukların ortaya çıkmasına neden olmuştur. Tarım toplumundan sanayi toplumuna geçişte hızlı bir değişim olmuş, köyden kente göç yoluyla oluşan toplumsal katmanlardaki sağlıksız değişimler çeşitli toplumsal çarpıklıkları getirmiştir. Köy-kent kültürü arasında bir varoş kültürü oluşmuş, popüler yapılanmaların çarpık yansımaları özellikle bu kesimlerde etkili olmuştur. Önemli bir seçmen sayısını oluşturan ara-kültür toplulukları Türkiye'de uzun yıllar oluşturulmaya çalışılan "modern toplum kültürü” nü bozmaya ve popüler kültürün niteliklerini egemen kılmaya başlamıştır. Popüler kültür konusu içindeki en önemli alan müziktir. Yaratılan kimlik erozyonunu, birey var olma mücadelesi vererek gidermeye çalışır. Mücadele süreci, sahte kimlik kazanımına yol açar. Gruplarla gidilen konserler, kült haline getirilen sanatçılar ve onlara duyulan hayranlık müziğe duyulan ilgiden çok metalaşmış bir müzik 
ortamını tanımlar. Bu aktivitelerle kitleyle bütünleşmeye çalışan birey, kendi içi dünyasının şizofrenisini dışlayarak öne çıkma, bütünleşme ironisiyle hiçliğini eritmeyi amaçlar. Gündelik yaşamın ortasına yerleşen müzik adına her şey sahiplenilip tüketilmesi gerekendir. Kimlik ancak tüketilenin ne olduğuna göre betimlenmektedir. Medyada yer alan parçaları mırıldanamıyor, onları söyleyenlerin özel yaşamını bilmiyorsanız, ait olduğunuz sosyal bir grup yok demektir (Vural Yıldırım, Tarkan Koç, Müzik Felsefesine Giriş, Bağlam Yayınları, 3.Baskı, İstanbul, 2006: 97).

Popüler kültür, iktidarın manipüle edici bir alanıdır. Müzik bu alanın ileti kodlarındandır. Popüler müzik, kente uyum sağlama sürecinin ara durumu iken zamanla bireyi kuşatarak yaşamın kendisine dönüşür. Kimlik problemi popüler müziğin sıradanlığı ve yarattığı sahte grup simülasyonu ile çözülür. Batı dünyasında 20. yüzyılın sonlarında başlayan küresel ekonomi ve siyasetlerin yarattığı ileri kapitalist kültürün sonuçları "postmodern dönem” olarak yaşanmaya başlamıştır. Postmodern dönem modern dönemin bir alternatifi olmaktan çok onun sonucudur. Postmodernizm olarak bilim dünyasında çok yönlü tartışma yaratan durum kültürel boyutlarıyla sanatı etkilemiş, hatta "postmodern sanat" kavramının doğmasına neden olmuştur. Postmodern durum kapitalist küresel gelişmenin kaçınılmaz bir sonucu olarak değerlendirilebildiği gibi; ulus devlet sistemlerinin çözülmesinin siyasal sonucu olarak ta görülebilmektedir. Postmodern durumu bütünüyle olumsuzlayan yorumlar olduğu gibi, bu durumun aslında modernizmin egemen ve seçkinci yapısına karşı bir çözüm olduğu görüşü de yaygındır. Ancak bu görüş bile postmodern durumun yansımalarını bütünüyle onaylamamaktadır. Türkiye gibi modernleşme sürecini sağlıklı olarak tamamlayamamış ülkelerde postmodern süreç doğal bir sonuç olarak gelişmemiş, bir kültürel ödünç alma ya da bir kültür ithalatı biçiminde kabul edilmiştir. Henüz modernleşme sürecini tamamlamamış toplumsal yapı, dıştan gelen yoğun kültürel baskı karşısında bilinçsiz ve savunmasız kalmıştır. Sanatlardapostmodernizm tartışması 1970’lerden günümüze kültür ve bilim tartışmalarının gündemine oturmuştur. Sanatın bir tüketim toplumu ürünü haline gelmesi, medyanın ve medya iletisi olarak sanat ürününün çoğaltılması ve sanat beğenisinin kitleselleşmesi çağın sorunları olarak algılanmaktadır (Andreas Huyssen, Modernite Postmodernite, der. Mehmet Küçük, Vadi yayınları, İstanbul, 1993: 230).

Politik ve toplumsal değişimler postmodern kültürün ortaya çıkışını kolaylaştırıcı uygun ortam yaratmıştır. $\mathrm{Bu}$ ortamdan tek başına bir durumu sorumlu tutmak yanlıştır. Postmodernizmi hazırlayan koşullarda sanatın da rolü olmuştur. Rönesans’tan 19 yüzyıla kadar geçen süreçte sanat kendisini geliştirip arıtırken halkla bağlarını koparmıştır. Nitelikli sanat "yüksek sanat" olarak sınırlı eğitimli bir kitleye seslenebilir hale gelmiştir. Uzun bir dönem bu boşluk yerel ve otantik üretimlerle doldurulmuş, ya da "yüksek sanatın" kötü kopyaları "kitch" ürünler üretilmiştir. Ancak teknolojinin gelişmesi ve sanat ürünlerinin çoğaltılıp yaygınlaştırılması yüksek sanatın topluma kapalı, korumalı yapısını sarsmıştır. Artık hiçbir değer korunup saklanamaz hale gelmiştir. En olağanüstü sanatsal buluşlar moda tüketimlerin parçası haline getirilmiştir (Andreas Huyssen, Modernite Postmodernite, der. Mehmet Küçük, Vadi yayınları, İstanbul, 1993: 126).

Sanatın toplumsal ortamda bireyleri etkileme gücü siyasal sistemlerde çoğunlukla tehlikeli 
sayılmış, toplumsal bilincin değişim ve dönüşümündeki etki gücü sansüre uğratılmıştır. İnsan tüm düşünüş ve duygulanımlarının yanı sıra siyasal görüş, özlem ve eleştirilerini de sanat yoluyla ifade etmeyi seçmiştir. Bu seçim doğal bir seçimdir. Ancak siyasal sistemler bu duygu, düşünce ve özlemlerin kendi hedefleriyle uyuşmadığı zamanlarda sanatın özgür ifade dilini engellemek istemişlerdir. Dünya tarihi bunu en acı biçimde Hitler rejiminde yaşamıştır. Ülkemizde de kritik siyasal dönemler sanatın sansürlendiği dönemlerdir. Sanatın eğlenme ve vakit geçirme işlevi güçlendirilerek, düşünme ve eleştirel görüş sunma işlevleri zayıflatılmaya çalışılmıştır. Sanat çoğunlukla toplumsal bir kimliğin dili olarak tanımlansa bile her durumda uyumla kabul edilen bir üretim biçimi değildir. Sanatın etki alanı, gücü, kolektif duyguları canlandırmadaki yetkinliği zaman zaman tehlike olarak görülmüştür. Bu nedenle sanatın eğlendirici ve oyalayıcı yanı teşvik edilirken, özgürleştirici ve düşündürücü yanı yıkıcı bulunup yasaklanmaya çalışılmıştır. Sanat apolitik bir üretim değildir. Her sanatçı açık ya da üstü örtülü biçimde bir dünya görüşüne sahiptir ve bu sanat ürününe yansır (Ahmet Oktay, Sanat ve Siyaset, Yön yayıncılık, İstanbul, 1991: 52).

Türkiye kültüründe sanat apolitik, eğlendirici ya da ritüelik unsurları öne çıkarılan bir üretim biçimi olarak kabul edilmiş, düşünceyi açığa çıkaran, özellikle eleştirel düşünceyi ortaya çıkaran ürünler ideolojik olarak kabul edilip yasaklanma ya da engellenme yoluna gidilmiştir. Adorno’nun “özgürlük hiçbir zaman verili değildir, her zaman tehdit altındadır” sözlerinde de görüldüğü gibi gerek üslup olarak, gerek dinletideki yenilikler insanları sürükleyeceği korkusuyla tehlikeli sayılmıştır. Bu toplumsal yönetim tutumu, zaten az olan sanat üzerine düşünme alışkanlığını bütünüyle azaltmış ve sanatın eleştirel gücü yok edilmeye çalışılmıştır. Ülkemizde sanat eğitimi bağlamında müzik eğitimindeki kültür ve sanat politikaları bilimsel bir disiplin olarak eğitim alanına girememiştir. Yukarıda çeşitli boyutlarıyla incelenen sanat politikaları olgusu müzik insanları tarafından büyük ölçüde algılanamamaktadır. Sanatın olumsuz kültür politikalarının malzemesi olmasını engelleyebilecek bilinçli direnç ancak müzik insanlarından gelebilir. Eğer müzik eğitimi ile ilgilenenler; müziğin toplumsal kimlik üzerinde uygar kültürel değer olarak yaşanması ve algılanmasını kurgulayıp savunamazlarsa bugün içinde bulunduğumuz durum gibi, sanat dışı olguların belirlediği kültür politikalarının baskıcı etkisi altında kalmaları kaçınılmazdır. $\mathrm{Bu}$ nedenle sanatın diğer kuramsal birikimlerinin güçlendirilmesi bağlamında kültürel politikalar konusunda yoğun bilinçlendirme eğitimleri yapılmalıdır.

\subsubsection{Müziğin Psikolojik Boyutu}

Müzik, içinde yoğun şekilde duyuş, düşünüş ve davranış barındıran bir süreçtir. Müzik süreç içinde gerçekleşir, başlar ve biter. Belli bir zaman ve uzam içerisinde bir akıcılık gösterir. Bu süreç içerisinde müzik, dinleyici tarafından alınır, duyulur, düşünüş ve davranış geliştirmesine sebep olur. Müzik psikolojisi, bir bilim dalı olarak tüm bu unsurları göz önünde bulundurmak koşuluyla, müziğgin birey ve toplum psikolojisi üzerindeki etkilerini bilişsel, gelişimsel ve kültürel yönleriyle inceler. Her sanat dalında olduğu gibi müzik sanatında da öncelikle duygulara yönelik insani edim vardır. Bu edimin insani yönünün olması müzisyen tarafından üretilmesinden kaynaklanır. İnsanlar müzikle düşünür, onunla kendilerinin kim olduğuna karar verip, kendilerini anlatır (Vural Yıldırım, Tarkan Koç, Müzik Felsefesine 
Giriş, Bağlam Yayınları, 3.Bask1, İstanbul, 2006: 28).

Modern bilim müziğin psikolojik etkileri konusunda çok çeşitli araştırmalar yapmıştır. Henüz bütün gerçekliğe ulaşılmamış olsa da müziğin psikolojik etkilerinin büyük bölümü artık bilinmektedir. Müziğin psikolojik etkisi müzik eğitiminde kullanılmalıdır. Ancak günümüzde bu göz ardı edilmektedir. Özellikle çocuğa yönelik müzik eğitiminin çocuk duygulanımlarına, neşesine ve enerjisine uygun seçimler konusunda ciddi araştırmalar eğitime yansıyamamıştır. Oysa müzik dinlemenin birinci koşulu ondan kendimize, duygularımıza pay çıkarabilmemizdir (Sufi Inayat Khan, İnsan ve Evren Arasındaki Köprü, Müzik, Arıtan Yayınevi, çev. Kaan Ökten, Tuğrul Ökten, İstanbul, 1994: 138).

Müzik psikolojisinin araştırma alanlarından biri olan sanat tüketicisinin duyuşsal ve duygusal tepkileri, müzik insanlarını yakından ilgilendirmektedir. Sanatçı yarattığı ürünün tüketicisi üzerindeki etki alanını tasarlar. Kendi duygulanımlarını tüketicisine aktarabilmek için ona müziksel ipuçları sunar. Sanatçı-tüketici ilişkisinin çok boyutlu olduğu düşünülürse bunlardan tematik ilişki sanat psikolojisinin sadece küçük bir araştırma alanını oluşturur. İnsanlık müzikte sürekli bir arayış içindedir. Enstrümanlar, sesler, ritimler çağın yaşam gereksinimleri ve insanın kendini arayış yöntemleriyle paralellikler taşır. Bir müzik parçası bestelendikten sonra sanatçısıyla bağını koparır. Hatta büyük ölçüde enstrümanla da bağını koparır. Dinleyici melodiden etkilenir. Onun bir keman ya da piyano ezgisinden olmasından değil. Bu nedenle insana ulaştırılan müzikte ulaşılan şeyin bir duygu ve düşünce anlatımı olduğu kabul edilmelidir. Yaşantısını büyük ölçüde otomasyon ya da ileri teknolojide geçiren bir insanın tını ve ritim arayışı müzik estetiğinin klasikleri arasında olmayabilir. Önemli olan dilin doğru oluşturulmasıdır. Hangi çalgıyla oluşturulduğuna ilişkin tutucu tutumlardan vazgeçilmelidir. Metroda klasik gitar dinletisi yapmak olanaksızdır (Sufi Inayat Khan, İnsan ve Evren Arasındaki Köprü, Müzik, Antan Yayınevi, çev. Kaan Ökten, Tuğrul Ökten, İstanbul, 1994: 152).

Sanat psikolojisi kapsamında müzik psikolojisi sanatçının yaratım süreçlerini açımlamaya, nedenselliklerini ve yaklaşımlarını irdelemeye yönelik analizler yapar. Sanatsal yaratım anının psikolojik boyutları ve sanatçının psikolojik kimlik özelliklerinin ürününe yansımasına ilişkin verileri değerlendirir. Müzik psikolojisi ürünün seslendirilişinin ardından insan psikolojisi üzerindeki etkilerini estetik kurallar dışında duygusal boyutta inceler. Psikopatolojik durumların sanat ürünü yoluyla iletimi de sanat psikolojisinin sorunları arasındadır. Bir ürünün psikolojik analizinden yola çıkılarak sanatçısının psikolojik portresi tespit edilebilirken; sanatçı portresinden yola çıkılarak ürünün psikolojik boyutları da tespit edilebilmektedir. Bir bilim dalı olarak ortaya çıktığı dönemden günümüze psikoloji bilimi sanatçıların ve sanat eğitimcilerin ilgisini çekmiştir. Özellikle psikanaliz, sanatçı ve ürün analizlerinde kullanılmış, psikanalitik kuramlar çerçevesinde ürünlerin gizli kalan yanları anlaşılabilir açıklamalara kavuşmuştur (Üstün Dökmen, Anadolu Üniversitesi Güzel Sanatlar Fakültesi 10. Sanat Sempozyumu, Eskişehir, 1995: 169).

Sanatçılar diğer birçok insan gibi kendi yaşamlarından söz ederken soyut kavramları somutlaştırmaya çalışırlar. Kimlik ve günlük yaşam politikalarına ait fikirlerini daha geniş olan fikirlerle, 
hem kendileri, hem de başkaları için birleştirirler. Sanatçı hiçbir zaman tarafsız olmamıştır. Kimlik ve politika hakkındaki fikirleri bazen otorite kazanmak bazen de otoriteyi korumak için kullanırlar. Oysa diğer sanat dallarında olduğu gibi müzikte de müziğin yaratıcısı olan sanatçılara bir müzik bilimi olarak dikkat edilmemiştir. Gerek müzik psikolojisi gerekse sanatçının toplumsal kimliği boyutunda sanatçıya bakabilmek, onları bir topluluk olarak kendi aralarındaki ilişkilerle inceleyebilmek gerekir. Kuşkusuz bu inceleme bize müzik sanatı hakkında doğrudan bilgi vermeyecektir. Ancak bu inceleme müziği anlamamızda ve nedenselleştirmemizde doğru açıklamalar yapabilme olanağı verecektir. Müzik üreten sanatçıların bir sosyal yaşantılarının olduğu, bu yaşantı içerisinde birbirlerini belirli bir rekabet ortamında etkilediklerini görebilmek gerekir. Örneğin sadece “ünlü olma” olgusu bile müzik sanatının biçimlenmesinde önemli belirleyici öğelerden biridir (Julian Gerstin, Toplum ve Bilim Dergisi, Nisan, İstanbul, 1994: 115).

Sanat psikolojisinin en geniş inceleme alanı yaratıcılık olgusudur. Yaratıcılığın geliştirilmesi ve geliştirilmesinde kullanılacak yöntemlerden, yaratıcılığg engelleyen etmenlerin ortadan kaldırılmasına yönelik teorilere kadar yaratıcılığa ilişkin çok sayıda analiz sanat psikolojisinin temel konuları arasında yer alır. Sanat psikolojisi boyutunda müzik psikolojisi de müziksel yaratıcılık üzerine deneysel ve kuramsal çalışmalar yapar. Çağımız müzik eğitiminin sanat psikolojisi açısından en bilinen varsayımlarından birisi müzik eğitimi yoluyla yaratıcılığın geliştirilmesidir. Sanat öncelikle bir zaman çizelgesidir. Bilgi de yetenek de o zaman temposunun içinde kendini var edebilir. Sanatta yaratıcılık uzun evreli bilgi ile anlam kazanır. Yaratıcılık anı bazen birkaç dakikadır. Ancak samimi duygularla yapılan keşifler, buluşlar sadece o anın birikimini ortaya koymaz. Sanatsal yaratıcılık uzun zaman dilimine dayalı, sanatı anlama, gerekçelerini ve gerçekliğini arama sanatçıların ürünlerini yoğun olarak yayabilme süreçlerinden sonra zihinde bir mozaik olarak ortaya çıkar. Sanatçı yaratım anında bu mozaiğin karelerinden seçmeler yapar (Regis Debray, Sanat Aşkıyla, Entelektüel bir öğreti, Çev. Nasuhi Güpgüp, Sel yayınc1l1k, İstanbul, 1999: 130).

Her sanatçı kendini orijinal kabul eder. Oysa hiçbir sanatsal buluş bütünüyle orijinal değildir. Çünkü o sanatsal buluşu besleyen düşünsel ve kuramsal altyapı bilimin kolektif dünyasında üretilmiştir. Sanatçının yaratıcılığını kullanırken bu dünyadan ne kadar alıntı yaptığı kesin bir dille saptanamaz yapar (Regis Debray, Sanat Aşkıyla, Entelektüel bir öğreti, Çev. Nasuhi Güpgüp, Sel yayıncılık, İstanbul, 1999: $150)$.

Müzik eğitimi veren kurumlarda yaratıcılık teorilerine ilişkin bilgi birikimi eğitsel amaçlı verilmektedir. Oysa yaratıcılık olgusunun sanatçı birey kimliğinde de anlaşılması gerekmektedir. Sanatçının biçemi, yaratım tarzı ve tematik örgüsünün anlaşılması boyutunda da yaratıcılık kuramları incelenebilmelidir. Ülkemizde bu konuda yapılan yayınlar büyük ölçüde çocuk yaş grubunun özelliklerine göre düzenlenmiştir. Sanatçının yaratıcılığg, sanat ürünü analizi için olmazsa olmaz bilgi birikimi olarak kabul edilmelidir. 


\subsubsection{Müzik Eleştirisinin Eğitsel Boyutu}

Sanat eleştirisi sanatın başlangıcından günümüze kadar sanata paralel olarak gelişmiş ve çok sayıda bilimsel kuram üretmiştir. Eleştiri günlük dilde algıladığımız biçimde bir durumun eksiklik ve yanlışlıklarını bulmakla sınırlı değildir. Sanat eleştirisi sanatı, sanat ürününü ve sanatçıyı anlamayı, anlamlandırmayı ve çözümlemeyi amaçlar. Kuşkusuz bu edimin içinde yaklaşımlara değerlendirmeler yaparken görülen tutarsılılılar ve yetersizlikler de ifade edilir. Müzik eleştirisi salt beğeni tartı̧̧ması değil, beğeninin nitelikleri ve kriterlerinin de tartışılmasıdır. Hepimizin yakından bildiği gündelik yaşamda sık sık işittiğimiz bir söz vardır. "Zevkler beğeniler üzerinde tartışılmaz." Bu yargı sıradan insan için doğru gibi görülebilir. Ancak sanatçının zevkleri ve beğenileri söz konusu olduğunda bunun tartışılmaması olanaksızdır (İsmail Tunalı, Estetik, Remzi Kitabevi, 9.basım, İstanbul, 2005: 259).

Estetik beğeniyi genel kılan bir takım ilkeler vardır. Bu ilkeler ortak estetik duygusu yaratan ilkelerdir. Ortak estetik duygusunu yaratan ilkeler sanatın estetik ilkeleridir. Bu ilkeler düşünce ile düşüncenin sanatın diline dönüşmesi arasındaki ilişside anlam bulur (İsmail Tunalı, Estetik, Remzi Kitabevi, 9.basım, İstanbul, 2005: 264).

Gerek kültür gerekse eğitim bakımından dünya içinde yaşadığımız dönemde giderek birbirine daha fazla yaklaşmakta, hatta birbirinin içinde erimektedir. Özellikle eğitimde geniş kitlelere yönelik eğitim araçları çoğaldıkça ortak beğeninin yaygınlaşması kısa zamanda gerçekleşmektedir. Bir kültür olgusu olarak sanat ve sanatın ürünlerinin yayılması günümüz koşullarında hızlı ve geniş alana yöneliktir. $\mathrm{Bu}$ olanaklar sanata yönelik beğeni ve seçkiyi güçlendirmektedir. Ancak bu olanakların kullanımı aynı oranda beğeninin ve seçkinin moda gibi sanat pazarı gibi olumsuz faktörlerin de yayılmasını hızlandırmaktadır. $\mathrm{Bu}$ olumsuz faktörlerle savaşım aynı kanalların gerçek sanat için kullanılmasını sağlayabilmekten geçer (İsmail Tunalı, Estetik, Remzi Kitabevi, 9.basım, İstanbul, 2005: 266).

Müzik eleştirisi, kuramsal boyutunun yanı sıra müzik tüketicilerinin müzik ürünlerine bilinçli yaklaşımlarını sağlayabilecek bir birikim yaratır. Sanatçı boyutunda müzik eleştirisi verileri, sanatçıyı yönlendirici işlevler de üstlenir. Ancak, bilimsel boyutlarda gerçekleştirilemeyen müzik eleştirisi sanat ortamında çeşitli tartışmalara neden olur ve ne toplum ne de sanatçılar tarafından ciddiye alınmaz. Eleştiri demokratik kültürün önemli özelliklerinden biridir. Gerek sanatçı gerekse sanat tüketicisi eleştirinin yönlendirici özelliğine güven oluşturamazsa, onun verilerinden yararlanması olanaksızlaşır. Müzik eleştirisi müzik eğitiminin önemli bir parçası olarak geliştirilmek durumundadır. Müzik eleştirisi olmaksızın eğitim ortamında müzik kuramlarının ve teorilerinin öğretilmesi kurallar dizgesinin tek yanlı, yorumlamadan uzak ve tartışılmadan ezberlenmesini getirir. Böyle edinilmiş bir müzik birikimi ise verimsiz ve işlevsizdir. Toplumumuzun dokusunda 1950'li yıllardan başlayan olumsuz değişimler müzik alanında çağdaşlaşmayı engellemiştir. Çağdaşlaşma rastlantıya bırakılmış, cumhuriyetin kültürel değerleri unutularak birçok olumsuz etkilenmeyle müzik beğenisi erozyona uğramıştır. 1970'li yıllardan başlayarak müzik eğitimi veren kurumların sayısında önemli artışlar olmuş, müzik eğitimi kurumları hemen hemen bütün üniversitelerde açılmış olmasına karşın genel anlamıyla müzik kültürümüzde çağdaşlaşma 
gerçekleşememiştir (Ahmet Say, Müzik Yazıları, Müzik Ansiklopedisi Yayınları, İstanbul, 2007: 34).

Müzik eleştirisi, genel tanımıyla bir eserin yorumunu, niteliklerini, değerini, başarılı ve başarısız yönlerini, estetik ve teknik ölçütlere göre araştırıp çözümleyerek yargılama yoluyla değerlendirir. Yargılama bir kritik yapmadır. Müzik diliyle iletilen bir bildiri olan müzik eserinin özünde "müzik iletişimi " vardır. Müzik bu iletişim sürecinin dört öğesi sayesinde ortaya çıkar: besteci, eser, seslendirici ve dinleyici. Eğer iletişim zincirinin halkalarından biri eksik kalırsa müzik sanatından söz etmek olanaksızlaşır. Besteci bildirisini ortaya koyar, seslendiriciler onu dinleyiciye iletir, dinleyici de bildiriyi algılar. Müzik iletişiminin son halkası olan dinleyiciler olmadığı zaman da müzik tamamlanamaz. Müzik iletişim öğelerinden birinin niteliği ötekilerini etkiler. Düzeyi düşük bir bestecinin seslendirici ve dinleyiciyle gerçek bir buluşma sağlaması oldukça güçtür. Seslendirici yetersizse dinleyici müziğe ilgi duymaz, besteciye hiç ulaşamaz. Dinleyicinin düzeyi düşükse besteci ve seslendiricilerin düzeyleri ne olursa olsun müzik bildirisinin niteliği cılızlaşır (Ahmet Say, Müzik Yazıları, Müzik Ansiklopedisi Yayınları, İstanbul, 2007: 54).

Ülkemizde müzik eğitimi veren kurumlarda müzik eleştirisine yönelik bilgi ve deneyimler aktarılmadığı gibi, kültürel yaşam ortamında da eleştirel bakış bilinci genel örgün eğitim anlayışından kaynaklı olarak gelişememiştir. Müziğin derinliklerini ve işitilen seslerin alt anlamlarını kavramayı sağlayacak bilgi birikiminden yoksunluk, beğeni düzeylerinin de yüzeysel ve dış biçime bağlı kalmasını getirmiştir. Müzik eğitiminin akademik alanlarında yüksek lisans aşamasında eleştiriyi kapsayan dersler açılmış olmasına karşın bunların toplumsal yaygınlığa ulaşması sağlanamamıştır. Akademik planda daha çok eğitsel amaçla müzik eleştirisine temel olabilecek eleştiri yöntemlerine ağırlık verilir. Bu teorik eleştiri yöntemlerini öğrenmenin aydınlatıcı ve yönlendirici yararlar sağlayacağı açıktır. Ancak bir eleştiri çalışmasını yöntemler kapsamındaki çerçeve değil, eleştirmenin düşünce ve sanat kavrayışından kaynaklanan araştırmacı, irdeleyici yaklaşımı ve onu ifade etme yetisi belirler (Ahmet Say, Müzik Yazıları, Müzik Ansiklopedisi Yayınları, İstanbul, 2007: 54).

Müzik özünde kültürel bir olgudur; kültürün mayalanması ve gelişmesini doğrudan etkiler; geçmiş ile gelecek arasında bağlar kurar. Müzik kültürün hem nedeni hem de sonucu olan insan değerlerini dile getirir. Sesler aracılığıyla anlatılması bakımından müzik, dolaylı, soyut bir ifade biçimidir. Ancak biz müzik yoluyla duygularımızı, acıyı, aşkı, protestoyu ve insanoğlunun birçok ruhsal davranış biçimini hissedebiliyoruz. Müzik yapmak yalnızca bir teknik beceri olsaydı sayılan ruhsal davranış biçimleri müzikle ifade edilemezdi. Ne yazık ki gençlerimiz konservatuar öğrenimini müzikte teknik beceri kazanmak olarak algılıyor. Bu yüzden müzikçi yetiştiren bu okullarımızda müziği bütün derinliğiyle kavramış sanatçı değil, daha çok beceri ustalığıyla yetinen çalgı teknisyeni yetiştiriyoruz. Müzik eleştirisinin kuramsal boyutu, sanatın yaratılma süreçlerindeki seçkilerin oluşturulmasında düşünsel zemin hazırlar. Sanatçı, seçkilerinin nedenselliğini ekoller ve ekol teorileriyle açıklarken eleştiri kuramlarının öne sürdüğü nedenselliklerle ürününü gerekçelendirir. Bir sanatçının derinlemesine tanıdığı ve bildiği eleştiri kuramı ne kadar zenginse, ürünlerini oluştururken yaratıcılığını eklemlediği düşünsel içerik de o denli zenginleşir. Felsefi ekoller ve dizgeler bir sanat yapıtının içeriğinin açıklanmasına çaba 
harcadığında, estetik kaygının yanı sıra aynı zamanda yöntemsel açıklama sorunlarıyla da yüz yüze gelir. Çünkü bir sanat yapıtının kavramsallaşmış içeriğinin çözümlenmesi ayrı ayrı anlatım biçimleriyle gerçekleşir. Yorumbilimsel yöntem, olgubilimsel yöntem, materyalist yöntem, sanata farklı farklı yanlardan yaklaşır. Dolayısıyla sanat yapıtının algılanması, anlamlandırılması ve çözümlenmesi yöntemleri bize sanatın farklı bakış açılarından boyutlarını sunar. Bu boyutların her birini bilmek bizi sanat yapıtına bir adım daha yaklaştırır. Sanatçı o adımları kendi sanat ürününe de yaklaştırmalıdır (Prof.Dr. Şahin Yenişehirlioğlu, İmgelerin Sisi, Alkım kitapçılık yayıncılık, İstanbul, 1992: 71).

Sanat, tüm boyutlarıyla ileriye dönük, atılıma açık, yeniliği kendine 1şık edinen, genç olan öğeyi özleyen, taze bünyeyi gündeme getiren, oralarda yaratmayı uğraş edinen, eğitime yönelik bir pragsis, bir dinamik öğe, bir kendini arama, düşünme, sürekli olarak öznel boyuttan nesnel boyuta gidip gelmedir. Bu süreçte yer alan insan varlığına biz sanatçı diyoruz. O zaman sanatçı hep yeniyi arayan, kovalayan, hiç eskimeyen, önder kişiliği olan bir kimliktir. Müzik eleştirisi bilimsel boyutunun dışında sanatsal anlatım boyutu da olan bir uğraştır. Yazı diliyle müziğin derinliklerini anlatabilmek oldukça güç bir uğraştır. Bu nedenle müzik eleştirisi eğitimi müzik teorilerini kapsayan bilgi birikiminin yanı sıra, bilinçli bir dinleyici olmayı ve bilinçli bir edebi yazarlık birikimi gerektirir. Müzik üzerine düşünmek ve yazmak belki de müziğin kendisini yazmaya oranla her zaman eksikli kalmaya mahkûm bir girişimdir; çünkü başka hiçbir dile benzemeyen bir kodlama sisteminin anlaşılmasını, doğal olarak, sözün ve yazının hayal ufku içinde gerçekleştirmeye çalışılmasını gerektirir (Ali Ergür, Portedeki Hayalet (müziğin Sosyolojisi Üzerine Denemeler), Bağlam Yayınları, İstanbul, 2002: 17).

Müzik eğitimi kapsamında sanat eleştirisine ilişkin birikimler yoğun sanat tüketimi alışkanlığ1 gerektirir. Dinleme seçkisinin çeşitlenmesi ve müziğin yaşanıldığı her ortamda bulunabilmek, gözlemlerin objektif değerlendirmeyle yorumlanabilmesine katkıda bulunur. Müzik eleştirisi kuramsal boyutta derinleşmeyi sağlarken, yaşamsal boyutta da müziğin günlük hayatın içine bütünüyle yerleşmesini gerektirir. Eleştirmen müzikle soluk alabilmeyi bir yaşam biçimine dönüştürebilmelidir. Sanatçı ancak böyle bir eleştirmenin yorumunu samimi bulabilir. Sanatçı eleştirel seçkiye sahip olmalıdır. Bu seçkiye sahip olabilmesi için sırasıyla 1. Sezgi gerekir. Önyargı ya da peşin kavrayışlardan arınmak zorundadır. 2. İncelediği ya da odaklandığı sanat ürününün geliştiği kültür çevresi hakkında bilgi sahibi olmalıdır. 3. Eleştirdiği ya da odaklandığı sanatın dilinin ekolleri ve değerleri konusunda geniş bir kavrayışa sahip olmalıdır. Eleştirel tutum bu sahip olunan birikimle yetkinleşir (Sezer Tansuğ, Herkes İçin Sanat, Altın Yayınevi, Bilimsel sorunlar dizisi, 1982, İstanbul, s.234). Sanat eleştirisi boyutunda müzik eleştirisi eğitimi hem sanat eğitimcilerinin müzikte kaliteliyi seçebilme bilincini, hem de üretici boyutta sanatçının ürünlerinde özgünlüğü koruyarak kaliteli ürün verme seçkisini yaratır. Sanatçının kalıcı müzik eleştirisi ve değerlendirmelerini ciddiye alması, günlük moda beğenilerinin sanat üretimleri üzerinde sanat piyasası baskısı oluşturmasını engeller. Sanatçının ve eğitimcinin müzik eleştirisi konusundaki yetkinliği sanatın kültürel ortamda bozulması karşısında önemli bir savunma gücüdür. 


\section{SONUÇLAR}

Müziği incelemek bilim için herhangi bir şeyi incelemekten çok farklı değildir. Bilim için ne, nasıl ve neden sorularına yanıt aramaktır. Bilim dünyası da birçok sosyal alanıyla kendi verileri doğrultusunda bu soruya yanıt aramıştır. Müzik yapmak ve müziği incelemek ayrı ayrı eylemlerdir. Müzik yapmak; müziği icra etmek, söylemek, bestelemek anlamına gelir. Müziği incelemekse müzik adına kuramsal yöntemlere dayalı soruların yanıtını aramaktır. Türkiye bilim hayatı için, oldukça yeni olan bu bakış açısı günümüzde giderek önem kazanıp kabul görmeye başlamıştır. Ülkemizde uzun dönemler, müziğin icrası ve dinletilmesine yönelik çalışmalarla geçirilmiştir. Onu anlamlandırmak, nedensellik ilişkilerini irdelemek günümüze kadar yeterince ilgi görmemiştir. Kaynağından toplanan müzik eserleri (derlemeler) inceleme amaçlı olmaktan çok seslendirme amaçlı kullanılmıştır. Oysa disiplinler arası bir çabayla uygulama ve teori birikimleri bir arada kullanılarak eş zamanlı araştırmalar yapmak olasıdır. Müzik kaynağının kültürel kodlanması ve kavramsallaşması gibi kuramsal çalışmalar, müzik icrasıyla eş zamanlı gerçekleştirilmemiştir. Müzik üzerine söylem geliştirmek sanatçı ve müzik yaratıcısı üzerine düşünmeyi de gerektirir. Bir anlamda müzikal kimliği irdelemeyi zorunlu kılar. Bu çaba, müzik psikolojisini doğru birikimle kullanmayı da gerektirir. Oysa ülkemizde bu süreçler gerçekleştirilmeden, müzikoloji adına yalnızca müzik eserleri toplanmaya ve biriktirilmeye çalışılmıştır. Günümüzde tartışılan temel sorunlardan bazıları şöyle özetlenebilir. Eğitim sisteminin yeterince algılama, biçimlendirme, aktarma, düş gücü ve yargıya varma yetilerini geliştirememektedir. Okul yaşantısıyla toplum yaşantısı arasında ciddi kopukluklar vardır. Okullarda göreli olarak özgür ve gerçeklerden uzak yetiştirilen çocuk yetişkin olduğu zaman iş yaşantısında toplumla yüz yüze geldiğinde baş edilemez sorunlarla karşı kaşıya gelmektedir. Müzik üreticisini yaratıcı boyutta düşündüğümüzde kompozisyonu nasıl yarattığına dair incelemek gerekir. Kompozitör müziği işitilebilir sürece getirmeden önce düşünsel anlamda zihninde canlandırır. Daha sonra bir ya da birkaç çalgıda dener. İşittiklerinden emin oldukça bestesinin parçalarını eklemlemeye başlar. İşte bu emin olma noktası bir yandan onun aynı zamanda dinleyici olarak beğenisini ortaya koyduğu andır. Bu beğeniyi sağlayan şey yeteneği ve eğitimiyle gelişen kendi düşünce sistemidir. İki bestecinin aynı temada hatta aynı ekolde yazdığı eserlerin olduğunu biliriz. Ama ortaya çıkan müziğin aynı olmadığını görürüz. Bu bize bir müziği oluşturan şeyin bütünüyle içerik ya da biçim olmadığını gösterir. Müziği oluşturan şey yaratıcısının düşünsel seçkileridir. Bu düşünce alanı ne kadar geniş ve ne kadar çok kaynaktan besleniyorsa ürün o denli kapsamlı bir taşıyıcı olacaktır. Müzik felsefesi birikimi müziği yapan kimseye müziği yaratırken başvurduğu düşüncelerinin yorumlanması ve anlamlandırılmasında yardımcı olur. Müzik felsefesine ilişkin birikim ne denli kapsamlı ve zenginse müzik yapan kimse kendi düşüncelerini ve ilişkilerini o denli açı ve saydam değerlendirebilir. Müzik felsefesi besteciye doğal yaratıcılığını zihinsel üretime dönüştürme olanağ1 sağlar. Bu tıpkı bir öykü anlatısının olağanüstü bir (Peter Wolters, Berlin, Eğitsel Etken olarak Güzel sanatlar, redaktör Prof. Dr. İnci San, Alman kültür merkezi yayını, 1995, Ankara, s.26-27) edebiyat eserine dönüşmesi gibi büyük bir ayrıma dayanır. Besteci oluşturduğu tüm ezgi birimlerini hoşlanmak üzerine yapılandırmaz. Onlarla tepki yaratmak, bazen örneğin korkuyu açığa çıkarmak ister. Ancak bu noktada kendi korkularım tanıyabildiği gibi kendi dışındakilerin korkuları hakkında da fikir sahibi 
olmalıdır. Müzikte bir yapı arama, yapıyı oluşturan öğeleri belirleme, bu öğeler arasındaki uyumu sezme ve kavrama çabaları bestecinin sorumluluğundaki arayışlardır. Dinleyici için sorumluluk bütün bu arayışların sonucu olan ezgiyi algılayabilmek, anlayabilmek ve değerlendirebilmektir. Sanat bilim ve teknoloji ile giderek daha yoğun ve sıkı bir ilişki içine girmektedir. Sanat ile bilim ve teknik arasındaki sınırlar eski belirginliğini yitirmekte, kesişim alanları hızla büyüyüp genişlemektedir. Bir başka deyişle sanat, bilim ve teknoloji aralarındaki duvarları yıkmış, giderek iç içe geçen bir üretim alanına dönüşmüştür (Prof. Dr. Ali UÇAN, Anadolu Üniversitesi Güzel Sanatlar Fakültesi 10. Sanat Sempozyumu, Eskişehir, 1995: 124).

Bilgi toplumu olma yolundaki çabalara gittikçe daha sık rastlanılmaya başlanan ülkemiz Türkiye 'de bilimsel ve teknolojik bilgilerin yanı sıra sanatsal bilginin de daha yoğun ve kapsamlı olarak geliştirilip üretilmesi, daha yaygın ve etkin biçimde kullanılması beklenmektedir. Bu beklentinin gerçekleşmesinde sanat eğitimi veren yüksek okul kurumlarının sorumluluğu çok büyüktür (Prof. Dr. Ali UÇAN, Anadolu Üniversitesi Güzel Sanatlar Fakültesi 10. Sanat Sempozyumu, Eskişehir, 1995: 124).

Sanatla ve sanat yoluyla, sanat içinde ve sanat için eğitim yaklaşımları aslında birbirlerini tamamlayan bir bütündür. Bu bütünün tamamlayıcı olması yetenek eğitiminin yanı sıra bilgi ve teknoloji eğitimini de gerekli kılar (Prof. Dr. Ali UÇAN, Anadolu Üniversitesi Güzel Sanatlar Fakültesi 10. Sanat Sempozyumu, Eskişehir, 1995: 124).

Sanat doğrudan yararlılık üzerine amaçlarını belirlemez. Ancak her sanat ürünü kendi varlığını sürekli kılabilmek için doğrudan yararlı olmasa bile hiç değilse anlaşılmak ve hatırlanmak durumundadır. Anlamak ve hatırlamaksa nedenselliği bilinen durumlarda gerçekleşir. Müzik diliyle düşünebilmek, bu dille davranışları belirleyebilmek, bu dille insanları anlayabilmek ve en temel insani kaygılara bu dille çözüm aramak sanatın sınırlandırılması anlamına gelmez. Sanat, en doğal insani duyguların anlamlı zihin verilerine dönüşmesini sağlıyorsa, sanatsal üretim bu zihin verileri konusunda birikimli olmak zorundadır. Yaratmada rastlantılar olabilir. Ama bir ezgi duyulmaya başladıktan sonra rastlantı ortadan kalkmış, nedenselliği açıklanabilir bir gerçeğe dönüşmüştür. Tamamlanmış müzik kimliği oluşturmak, kolay ve dar bir rota çizmek değildir. Müziksel kimlik öncelikle bireyin kendisini sanatçı olarak kabul edebileceği derinliğini keşfetmesiyle başlar. $\mathrm{Bu}$ derinliğin gerçekliği ise ancak müzik bilimlerinin verileriyle kanitlanabilir.

\section{KAYNAKÇA}

Ali Uçan, (1996), Insan ve müzik, insan ve sanat eğitimi, 2.Basım, Müzik Ansiklopedisi Yayınları, Ankara.

A. A. Jdanov, (1996), Edebiyat, Müzik ve Felsefe Üzerine, çev. Fatmagül Berktay, Kaynak Yayınları, İstanbul, (149-155).

Nurettin Fidan, Münire Erden, (1986), Eğitim Bilimine Giriş, Kadığlu Matbaası, Ankara, (30-96).

Otto Karolyi, (1995), Müziğe Giriş, çev. Mehmet Nemutlu, Pan Yayınları, İstanbul. 
Anton Webern, (1998), Yeni Müziğe Doğru, Çev. Ali Bucak, Pan yayınları, İstanbul.

Sufi Inayat Khan, (1994), Insan ve Evren Arasındaki Köprü, Müzik, Arıtan Yayınevi, çev. Kaan Ökten, Tuğrul Ökten, İstanbul.

Avşar Timuçin, (2002), Estetik, Bulut yayınları, İstanbul, (66-105).

Aziz Çalışlar, (1986), Gerçekçilik Estetiği , D yayınevi, İstanbul.

Vural Yıldırım, Tarkan Koç, (2006), Müzik Felsefesine Giriş, Bağlam Yayınları, 3.Baskı, İstanbul.

Ayten Kaplan, (2005), Kültürel Müzikoloji, Bağlam Yayınları, İstanbul, (22-63).

Ken Baynes, (2002), Toplumda Sanat, çev. Yusuf Atılgan, Yapıkredi Yayınları, İstanbul.

Edip Günay, (2006), Müzik Sosyolojisi, Bağlam yayınları, İstanbul.

İbrahim Armağan, (1992), Sanat toplum bilimi, İleri Yayınları, İstanbul.

Ayhan Erol, (2005), Popüler Müziği Anlamak, Bağlam Yayınları, İstanbul.

Ömer Naci Soykan, (2000), Müziksel Dünya Ütopyasında Adorno ile Bir Yolculuk, Bulut Yayınları, İstanbul.

Nilüfer ÖNDİN, (2003), Sanat Dünyamız, sayı 89, Yapıkredi yayınları, İstanbul.

Andreas Huyssen, (1993), Modernite Postmodernite, çev. Mehmet Küçük, Vadi yayınları, İstanbul.

Ahmet Oktay, (1991), Sanat ve Siyaset, Yön yayıncıl1k, İstanbul, (41-45).

Regis Debray, (1999), Sanat Aşkıyla, Entelektüel bir öğreti, çev. Nasuhi Güpgüp, Sel yayıncılık, İstanbul. İsmail Tunalı, (2005), Estetik, Remzi Kitabevi, 9.basım, İstanbul.

Ahmet Say, (2007), Müzik Yazıları, Müzik Ansiklopedisi Yayınları, İstanbul.

Şahin Yenişehirlioğlu, (1992), Imgelerin Sisi, Alkım kitapçılık yayıncılık, İstanbul.

Ali Ergür, (2002), Portedeki Hayalet (müziğin Sosyolojisi Üzerine Denemeler), Bağlam Yayınları, İstanbul.

Sezer Tansuğ, (1982), Herkes İçin Sanat, Altın Yayınevi, Bilimsel sorunlar dizisi, İstanbul.

Enrico Fubini, (2003), Müzikte Estetik, çev. Fırat Genç, Dost Kitabevi, Ankara.

Anton Webern, (1998), Yeni Müziğe Doğru, çev. Ali Bucak, Pan yayınları, 1998, İstanbul, (113-147).

Ayhan Erol, (2005), Popüler Müziği Anlamak, Bağlam Yayınları, İstanbul.

Peter Wolters, (1995), Berlin, Eğitsel etken olarak güzel sanatlar, redaktör İnci San, Alman Kültür Merkezi Yayını, Ankara. 